\title{
Review
}

\section{Macrophages in Skeletal Muscle Dystrophies, An Entangled Partner}

\author{
Marine Theret ${ }^{\mathrm{a}}$, Marielle Saclier $^{\mathrm{b}}$, Graziella Messina ${ }^{\mathrm{b}}$ and Fabio M.V. Rossi ${ }^{\mathrm{a}, *}$ \\ ${ }^{a}$ School of Biomedical Engineering, Department of Medical Genetics, University of British Columbia, \\ Vancouver BC, Canada \\ ${ }^{\mathrm{b}}$ Department of Biosciences, University of Milan, Milan, Italy
}

Pre-press 17 September 2021

\begin{abstract}
While skeletal muscle remodeling happens throughout life, diseases that result in its dysfunction are accountable for many deaths. Indeed, skeletal muscle is exceptionally capable to respond to stimuli modifying its homeostasis, such as in atrophy, hypertrophy, regeneration and repair. In particular conditions such as genetic diseases (muscular dystrophies), skeletal muscle's capacity to remodel is strongly affected and undergoes continuous cycles of chronic damage. This induces scarring, fatty infiltration, as well as loss of contractibility and of the ability to generate force. In this context, inflammation, primarily mediated by macrophages, plays a central pathogenic role. Macrophages contribute as the primary regulators of inflammation during skeletal muscle regeneration, affecting tissue-resident cells such as myogenic cells and endothelial cells, but also fibro-adipogenic progenitors, which are the main source of the fibro fatty scar. During skeletal muscle regeneration their function is tightly orchestrated, while in dystrophies their fate is strongly disturbed, resulting in chronic inflammation. In this review, we will discuss the latest findings on the role of macrophages in skeletal muscle diseases, and how they are regulated.
\end{abstract}

Keyword: Macrophage, skeletal muscle, muscle dystrophy, repair, inflammation

\section{ABBREVIATIONS}

$\begin{array}{ll}\text { AMPK } & \text { AMP-activated Protein Kinase } \\ \text { BM } & \text { Bone Marrow } \\ \text { BMD } & \text { Becker Muscular Dystrophy } \\ \text { BMDM } & \text { Bone Marrow Derived Macrophages } \\ \text { C/EBP } & \text { CCAAT-enhancer-binding proteins } \\ \text { CCL } & \text { C-C chemokine ligand } \\ \text { CCR } & \text { C-C chemokine receptor } \\ \text { CK } & \text { Creatine Kinase } \\ \text { CSF } & \text { Colony Stimulating Factor } \\ \text { CTGF } & \text { Connective Tissue Growth Factor } \\ \text { CXCL } & \text { C-X-C chemokine ligand } \\ \text { CXCR } & \text { C-X-C chemokine receptor }\end{array}$

${ }^{*}$ Correspondence to: Fabio M.V. Rossi, Biomedical Research Centre, University of British Columbia 2222 Health Sciences Mall, Vancouver, British Columbia. Tel.: +1 604822 7138; Fax: +1 604 822 7815; E-mail: fabio@brc.ubc.ca.

$\begin{array}{ll}\text { DAMP } & \text { Damage-Associated Molecular Pattern } \\ \text { DGC } & \text { Dystrophin-Glycoprotein Complex } \\ \text { DTA } & \text { Diphtheria Toxin A } \\ \text { ECM } & \text { Extracellular Matrix } \\ \text { eMHC } & \text { embryonic myosin heavy chain } \\ \text { FAP } & \text { Fibro/Adipogenic Progenitor } \\ \text { GR } & \text { Granulocyte Receptor } \\ \text { GM } & \text { Granulocyte Macrophage } \\ \text { IFN } \gamma & \text { Interferon Gamma } \\ \text { IGF } & \text { Insulin-like Growth Factor } \\ \text { IL } & \text { Interleukin } \\ \text { LGMD } & \text { Limb-girdle Muscular Dystrophy } \\ \text { LTBP } & \text { Latent TGFß Binding Protein } \\ \text { LPS } & \text { lipopolysaccharide } \\ \text { MAPK } & \text { Mitogen-activated protein kinase } \\ \text { MHC } & \text { Myosin Heavy Chain } \\ \text { MKP-1 } & \text { Mitogen-activated protein kinase } \\ & \text { phosphatase 1 }\end{array}$




\begin{tabular}{|c|c|}
\hline MMP & Matrix Metalloproteinase \\
\hline MD & Muscular dystrophy \\
\hline MSA & Myositis-specific antibody \\
\hline NAMPT & $\begin{array}{l}\text { Nicotinamide phosphoribosyl- } \\
\text { transferase }\end{array}$ \\
\hline Nfix & Nuclear Factor I X \\
\hline $\mathrm{NF} \kappa \mathrm{B}$ & Nuclear Factor kappa B \\
\hline NSAID & Nonsteroidal anti-inflammatory drug \\
\hline OPN & Osteopontin \\
\hline PDGFR & $\begin{array}{l}\text { Platelet Derived Growth Factor } \\
\text { Receptor }\end{array}$ \\
\hline RANKL & $\begin{array}{l}\text { receptor activator of nuclear factor } \\
\text { NF- } \kappa \text { B ligand }\end{array}$ \\
\hline RANTES & $\begin{array}{l}\text { Regulated upon Activation, Normal } \\
\text { T Cell Expressed and Presumably } \\
\text { Secreted }\end{array}$ \\
\hline $\mathrm{SC}$ & Satellite Cell \\
\hline SCG & sarcoglycan \\
\hline TGF $\beta$ & Transforming growth factor beta \\
\hline TIMD4 & $\begin{array}{l}\text { T Cell Immunoglobulin And Mucin } \\
\text { Domain Containing } 4\end{array}$ \\
\hline TNF & Tumor Necrosis Factor \\
\hline Treg & regulatory $\mathrm{T}$ cell \\
\hline uPA & urokinase plasminogen activator \\
\hline VEGF & Vascular endothelial growth factor \\
\hline WT & Wild Type \\
\hline
\end{tabular}

\section{INTRODUCTION}

Disruption of homeostasis in skeletal muscle tissue can be triggered by many variables, including changes in diet or exercise, local injury, systemic infection, genetic disease, and ageing. In most of these cases, inflammation and in particular macrophages play a primordial role in the pathology. Macrophages, along with neutrophils, are part of the leukocyte family first described in 1908 by Elie Metchnikoff. In addition to their immunoprotective role against pathogens, macrophages have a number of additional roles during development and tissue remodeling, in particular in skeletal muscle [1-3].

Skeletal muscle regeneration is made possible by a population of adult muscle stem cells called satellite cells (SC) [4]. After damage or microenvironment changes, SCs activate, proliferate, and differentiate into myoblasts/myocytes before fusing with one another or with surrounding myofibers. As fitting their definition as a stem cell, SCs are capable of self-renewal which maintains a potent pool of cells throughout life (reviewed in [5, 6]). Despite the essen- tial role SCs play in muscle regeneration, these events won't happen without the help of other cells harbored in the interstices between the myofibers: endothelial cells, pericytes [7], fibro/adipogenic progenitors (FAP) [8-10], and foremost, macrophages [11-16]. Specifically, following damage, macrophages are responsible for the release of a pool of cytokines, chemokines and alarmins called damage-associated molecular pattern (DAMPs). These molecules are part of a coordinated response that initiates sterile inflammation and induction of blood-circulating monocytes' infiltration into the tissue.

In healthy tissue, successful skeletal muscle regeneration is typically complete within 3 weeks, and without any need for external intervention (antiinflammatory drugs for example) [17]. However, when disrupted, the process can take months and is often associated with fibrotic deposition (scarring) and adipogenesis. Examples of such disruptions in muscle homeostasis include repeated injures, volumetric mass injuries, modification in homeostasis during ageing (sarcopenia), prolonged immobility/atrophy (e.g. cancer: cachexia), genetic diseases that directly affect the muscle (e.g. Duchenne and Becker Muscular Dystrophies (DMD, BMD), and Limb-girdle muscular dystrophy (LGMD)).

In this review, we briefly describe the roles of macrophages in skeletal muscle regeneration, then turn our focus to their roles in muscular dystrophies (MD) and how current treatments act on their functions.

\section{MACROPHAGES, DEFINITION AND FUNCTION IN SKELETAL MUSCLE REMODELING}

To study muscle regeneration and inflammation, injury models that make use of toxins (notexin, cardiotoxin), chemicals (barium chloride) and mechanical trauma (crush, freezing, ischemia, laceration) are used to stimulate a response. Depending on the type of damage the kinetics of the inflammatory response will vary, however the overall regenerative process of the tissue remains the same (for more information about injury models, please read [18]).

The study of macrophages in vitro is usually conducted using bone marrow-derived macrophages (BMDM). Macrophage polarization in vitro is required to induce the secretion of specific cytokines associated to their functions such as phagocytosis of apoptotic cells, cell growth and tissue repair promotion, or fighting bacterial infections. Like $\mathrm{T}$ cells, 
Table 1

Monocyte/Macrophage populations

\begin{tabular}{|c|c|c|c|c|}
\hline & Population & Markers & Functions & References \\
\hline \multirow[t]{2}{*}{$\begin{array}{l}\text { Blood circulating } \\
\text { monocytes }\end{array}$} & Ly-6C+ & $\begin{array}{l}\text { Ly6C+, CCR2+, CD11blow, F480low, } \\
\text { CX3CR1low }\end{array}$ & $\begin{array}{l}\text { - Patrol blood system and } \\
\text { infiltrate tissues }\end{array}$ & {$[38,39]$} \\
\hline & Ly-6C- & $\begin{array}{l}\text { Ly6C-, CCR2-, CD11b+, F480+, } \\
\text { CX3CR1+ }\end{array}$ & - Patrol blood system & \\
\hline \multirow[t]{2}{*}{$\begin{array}{l}\text { Tissue resident } \\
\text { Macrophages }\end{array}$} & $\begin{array}{l}\text { Embryonic liver- } \\
\text { derived }\end{array}$ & $\begin{array}{l}\text { Ly6C-CCR2-F4/80hi CD11blow } \\
\text { Lyve1high }\end{array}$ & - unknown & {$[26,31]$} \\
\hline & $\begin{array}{l}\text { Adult bone } \\
\text { marrow-derived }\end{array}$ & $\begin{array}{l}\text { Ly6C-CCR2-F4/80low CD11bhigh } \\
\text { Lyve1low }\end{array}$ & - unknown & \\
\hline \multirow[t]{2}{*}{ Acute damage } & Ly-6C+ & $\begin{array}{l}\text { Ly6C+, CCR2+, CD11blow, F480low, } \\
\text { CX3CR1low, CD11c+ }\end{array}$ & $\begin{array}{l}\text { - Activate MuSC } \\
\text { proliferation. } \\
\text { - Phagocyte debris and dead } \\
\text { myofibers } \\
\text { - Kill FAPs }\end{array}$ & {$[17,52,56,59]$} \\
\hline & Ly-6C- & $\begin{array}{l}\text { Ly6C-, CCR2-, CD11b+, F480+, } \\
\text { CX3CR1+, CD11c+ }\end{array}$ & $\begin{array}{l}\text { - Support myogenesis and } \\
\text { myofiber growth } \\
\text { - Support FAP survival }\end{array}$ & \\
\hline \multirow[t]{2}{*}{ Chronic damage } & Ly-6Chigh & $\begin{array}{l}\text { Ly6Chi, CCR2+, CD11blow, F480low, } \\
\text { CX3CR1low, CD11c+ }\end{array}$ & $\begin{array}{l}\text { - Activate MuSC } \\
\text { proliferation. } \\
\text { - Kill FAPs }\end{array}$ & {$[56,59]$} \\
\hline & Ly-6C- & $\begin{array}{l}\text { Ly6C-, CCR2-, CD11b+, F480+, } \\
\text { CX3CR1+, CD11c+ }\end{array}$ & $\begin{array}{l}\text { - Activate MuSC } \\
\text { proliferation. } \\
\text { - Kill FAPs }\end{array}$ & \\
\hline
\end{tabular}

macrophages can acquire two main inflammatory profiles: classically activated M1 (related to type 1 inflammation - Th1) and alternatively activated M2 (related to Type 2 inflammation - Th2). The Th1/Th2 paradigm in macrophage has been extensively discussed and we encourage reading the following reviews $[19,20]$. BMDM are stimulated with IFN $\gamma$, IL-4/IL-13, or IL-10, to respectively mimic either the pro-inflammatory/classically activated state "M1", the alternative activation state "M2a", or the antiinflammatory state "M2c" [21]. Other M2 states have been proposed, such as M2b (immune complex activation [22]) and M2d (TLR antagonist [23, 24]), but are not relevant in muscle biology. Moreover, Lipopolysaccharide (LPS) alone or together with IFN $\gamma$, can be used to induce a stronger proinflammatory activation state. However, in the case of tissue regeneration and sterile inflammation, the use of LPS and of these in vitro methods in general might push macrophages into state not representative of that found in vivo.

\section{The understudied tissue-resident macrophages}

Skeletal muscle resident macrophages are quiescent cells, occupying space within the connective tissue that surrounds myofibers and in close proximity to blood vessels [25, 26]. As in other tissues, distinct subsets of resident macrophages arise from either developmental origins (yolk sac-, aorta-gonad- mesonephros- (AGM), or liver-derived hematopoiesis) or from the adult bone marrow (BM) [27]. It has been shown that tissue-resident macrophages acquire tissue specific functions. For example, Kupffer cells (liver) play a crucial role in the clearance of blood toxins, and alveolar macrophages (lung) will actively clean pathogens and microorganisms from the airways [28-30]. In skeletal muscle, so far the only proposed role of tissue resident macrophages is the attraction of circulating blood monocytes to the site of damage [26]. Yet, tissue resident macrophages are still heterogeneous, with a sub-type expressing stressresponse genes such as Klf2 or Fos [31].

It has been established that tissue-resident macrophages derive from primitive hematopoiesis in the liver and definitive hematopoiesis in the BM [32, 33]. As of now, the muscle research community lacks a specific marker to distinguish skeletal muscle resident macrophages from infiltrating monocytes. However, it seems that a proportion of resident macrophages are embryonically derived, while another subpopulation is maintained by blood-derived monocytes [31, 32, 34]. The embryonic-derived tissue-resident macrophages are $\mathrm{Ly}-6 \mathrm{C}^{-} \mathrm{CCR} 2^{-}$ $\mathrm{F} 4 / 80^{\text {hi }} \mathrm{CD} 11 \mathrm{~b}^{\text {low }}$, while the $\mathrm{BM}$-derived tissueresident macrophages are $\mathrm{Ly}-6 \mathrm{C}^{-} \mathrm{CCR} 2^{-} \mathrm{F} 4 / 80^{\text {low }}$ CD11b ${ }^{\text {high }}[32]$ (Table 1). More recently, the marker Lyve1 has been added to the list of the markers for tissue resident macrophages [31,35]. Wang et al., also suggest that Lyve1 expression (high versus low) 
could differentiate between the embryonic-derived (Lyve $^{\text {low }}$ ) and the blood-derived (Lyve ${ }^{\text {high }}$ ) tissue resident macrophages (Table 1). [31] In the heart, tissue-resident macrophages can be distinguished by expression of the marker T cell Immunoglobulin and Mucin Domain containing 4 (TIMD4). TIMD4 ${ }^{+}$ macrophages are able to locally self-renew, while TIMD4- cells are replaced by blood-derived cells [36]. Moreover, cardiac resident macrophages seem to have very specific functions depending on their location. For example, resident macrophages present in the atrioventricular nodes are required to maintain cardiac contraction via the formation of gap junctions with cardiomyocytes [37]. The regulation, self-renewal, and function of skeletal muscleresident macrophages at homeostasis and during regeneration is not yet understood. The characterization (ontology and specific markers) of this population should be definitively one of the focus points for better understanding of their function at steady state, during tissue remodeling (mild or acute damage), ageing, and in disease [2,30].

\section{Infiltrating monocytes and their function as macrophages}

\section{Circulating blood-monocyte infiltration}

In blood, monocytes separate into two subsets [38]. The first, which is CCR $2^{-} \mathrm{Ly}_{-} 6 \mathrm{C}^{-} \mathrm{CX} 3 \mathrm{CR} 1^{\text {high }}$ $\mathrm{CD} 11 \mathrm{~b}^{+} \mathrm{F} 4 / 80^{+}$functions to patrol the vasculature in search of pathogens [39] (Table 1). The other subset is CCR2 ${ }^{+} \mathrm{Ly}-6 \mathrm{C}^{+} \mathrm{CX} 3 \mathrm{CR} 1^{\text {low }} \mathrm{CD} 11 \mathrm{~b}^{\text {low }} \mathrm{F} 4 / 80^{\text {low }}$ and homes to damaged tissues primarily through the CCL2(MCP1)-CCR2 axis [40-44]. This cytokinereceptor interaction was one of the first described to induce monocytes infiltration into tissues after damage and has been observed as indispensable in liver, heart, and skeletal muscle [43, 45-47]. Since then, other chemokines have been described, such as: RANTES/CCL5, MIP3/CCL3, MIP4/CCL4, MCP-3/CCL7, MCP-4/CCL8 [48]. Sources of these chemoattractant can vary by tissue and context. For example, deletion of tissue resident FAPs using the PDGFR $\alpha$-CRE:DTA mouse model induced a strong reduction in infiltrating $\mathrm{CD} 45^{+}$cells after damage in skeletal muscle [49]. While this has not been backed up with migration assays in vitro, FAPs are known to produce and secrete MCP-1 and CSF1, which are known chemoattractant for leucocytes [50]. Alternatively, cells such as SCs and myofibers have also been shown to attract monocytes/macrophages $[51,52]$. Currently, only CCR $2^{+} \mathrm{Ly}-6 \mathrm{C}^{+} \mathrm{CX} 3 \mathrm{CR} 1^{\text {low }}$
$\mathrm{CD} 11 \mathrm{~b}^{\text {low }} \mathrm{F} 4 / 80^{\text {low }}$ monocytes are known to infiltrate damaged muscle $[11,17,53,54]$. One of the best pieces of supportive evidence comes from the use of the Nur77-KO mouse model. Nur77 (also known as NR4A1) is an orphan transcription factor involved in cell proliferation. Depletion of Nur77 induces a block in $\mathrm{S}$ phase, leading to apoptosis of Ly6C ${ }^{-} \mathrm{MO}$ in the bone marrow [55]. Interestingly, while Nur77-KO animals lack the Ly-6C ${ }^{-}$bloodcirculating monocyte population, Ly- $6 \mathrm{C}^{-}$macrophages are found in the muscle after acute damage in similar numbers to control littermates [53].

\section{Blood-derived macrophage functions}

The infiltration of monocytes and their differentiation into macrophages is essential for proper skeletal muscle regeneration [11, 16, 17, 40, 56-58]. Once extravasated, blood monocytes differentiate into inflammatory macrophages and lose CCR2 expression. Of note, this differentiation step is not fully understood yet and may be independent of the process leading to the appearance of alternatively activated and pro-regenerative macrophages (skewing), which is associated with the downregulation of Ly-6C [11, 53] (Fig. 1). Ly-6C ${ }^{+}$and Ly-6C ${ }^{-}$ macrophages are observed in a temporally precise sequence and are efficiently coordinated for skeletal muscle regeneration.

Pro-inflammatory macrophages $\left(\mathrm{Ly}-6 \mathrm{C}^{+} \mathrm{F} 4 / 80^{+}\right.$ $\left.\mathrm{CD} 11 \mathrm{~b}^{+} \mathrm{CX} 3 \mathrm{CR} 1^{\text {low }}\right)$ secrete cytokines and growth factors that support SC proliferation but induce death in FAPs [52, 56, 59]. Following the clearance of debris, dead cells, and necrotic myofibers, macrophages slowly activate a program that skews them towards a pro-regenerative phenotype (Ly$\left.6 \mathrm{C}^{-} \mathrm{F} 4 / 80^{+} \mathrm{CD} 11 \mathrm{~b}^{+} \mathrm{CX} 3 \mathrm{CR} 1^{\text {high }}\right)$, which supports myogenic cell differentiation and fusion $[17,52,60$ 62], and FAP survival [56, 59]. Knockout murine models have demonstrated the importance of this phenotypical skewing for efficient muscle regeneration and identified several actors guiding this process, including AMP-activated Kinase (AMPK), Mitogenactivated protein kinase (MAPK) phosphatase 1 (MKP-1), CCAAT-enhancer-binding proteins (C/ EBP $\beta$ ), and Nuclear Factor I X (Nfix) [17, 6365]. To note, in addition to Ly-6C, F4/80 and $\mathrm{CD} 11 \mathrm{~b}$, other markers can also be used to distinguish pro-inflammatory macrophages from the proregenerative type and are highlighted in Fig. 1 and Table 2. Through this process, macrophages are sensitive to and secrete various cytokines required 
Table 2

Markers for ma macrophages involved in skeletal muscle regeneration

\begin{tabular}{llll}
\hline Markers & Population & Functions & References \\
\hline CCR2 & Infiltrating monocyte & CCL2 receptor & {$[15,40-42,45,58]$} \\
iNOS & Pro-Inflammatory (Ly-6C+) & Transform Arginine in Nitric Oxid & {$[21]$} \\
Cox-2 & Pro-Inflammatory (Ly-6C+) & Catalyzes the conversion of arachidonic acid to prostaglandins & {$[16,21]$} \\
CD163 & Pro-regenerative (Ly-6C-) & Scavenger Receptor & {$[11,17]$} \\
Arginase 1 & Pro-regenerative (Ly-6C-) & Transform Arginine in Ornithine & {$[21,231]$} \\
Fizz1/RELMa & Pro-regenerative (Ly-6C-) & Pro-fibrotic secreted cytokine & {$[21,231]$} \\
CD206/MRC-1 & Pro-regenerative (Ly-6C-) & Mannose Receptor, specific function unknown & {$[11,17,21]$} \\
\hline
\end{tabular}
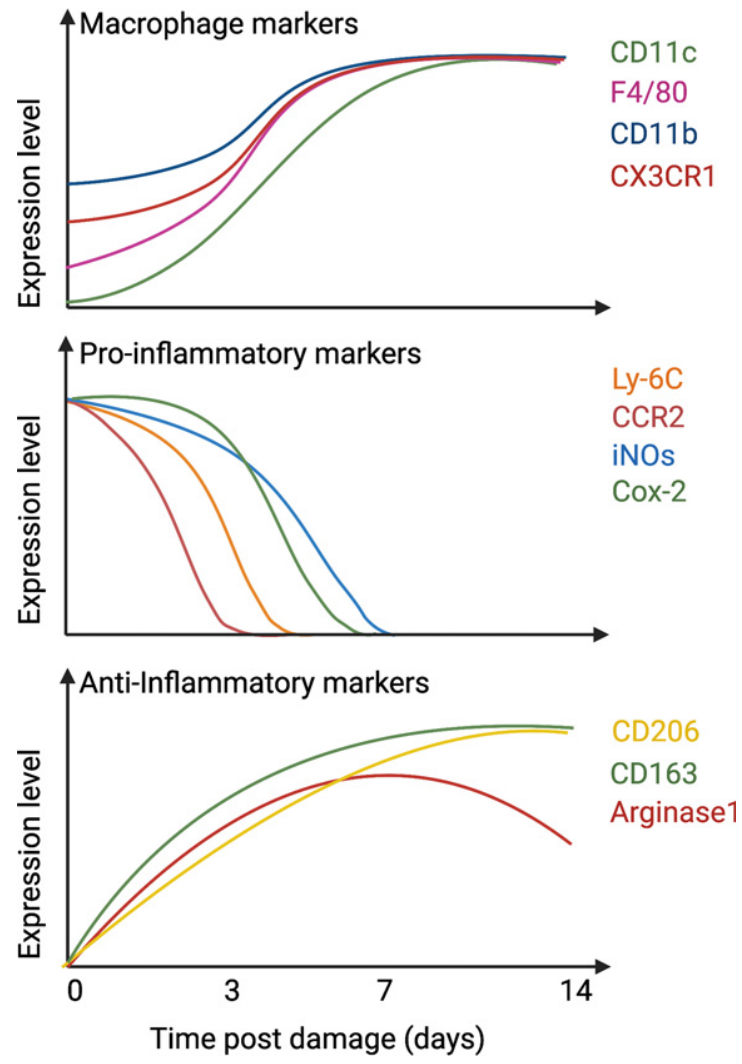

Fig. 1. Temporal expression of macrophage and inflammatory markers. After damage, infiltrated monocytes differentiate into macrophages, up-regulate CD11c, CD11b, F4/80, and CX3CR1 (top graph) and express pro-inflammatory markers such as Ly-6C, CCR2, iNOs, and Cox-2 (middle graph). After 1-2 days in the tissue, they downregulate pro-inflammatory markers and start to express anti-inflammatory proteins such as CD206, CD163, and Arginase 1 (bottom graph).

for efficient skeletal muscle regeneration, briefly described here (Fig. 2):

Annexins are known for their role in resolving inflammation by inducing neutrophil apoptosis and activating monocyte phagocytosis. Specifically, Annexin A1 has long been studied in vitro in models of tumor growth and arthritis [66, 67]. While
Annexin A1 is expressed by a number of cell types (FAPs, SCs, and macrophages), its receptor FFPR2 is expressed only by macrophages [68] and activates AMPK, promoting phagocytosis and inducing macrophage skewing toward a pro-regenerative phenotype $[17,61]$.

Insulin-like growth factor 1 (IGF-1) has been thoroughly described for its anabolic effect on skeletal muscle [69-72]. However, only more recently has it been shown to also be macrophage-derived. Indeed, deletion of IGF-1 in leukocytes using the Lysozyme $^{\mathrm{CRE}}$ mice induces a delay in muscle regeneration due to a defect in pro-regenerative phenotype switching [73].

Interferon gamma (IFN $\boldsymbol{\gamma})$ is a pleiotropic cytokine produced by various cell types and seems to have a dual role on myogenesis. So far, IFN $\gamma$ has been described as expressed by myogenic cells and NK cells, but not in macrophages [74,75]. However, macrophages are sensitive to IFN $\gamma$ 's effects as a pro-inflammatory cytokine. Consequently, IFN $\gamma$ signaling has to be quickly downregulated by regulatory $\mathrm{T}$ cells (Treg: FoxP ${ }^{+} \mathrm{CD} 4 \mathrm{~T}$ cells) in order for macrophages to resolve the inflammation and skew toward a pro-regenerative profile [75]. Interestingly, IFN $\gamma$ has been shown to have pro-myogenic functions as IFN $\gamma$-KO mice display impaired skeletal muscle regeneration [74]. However, over-stimulating human myoblasts with IFNy in vitro also leads to a defect in myogenesis, independently of myoblast apoptosis [76]. Moreover, IFN $\gamma$ has been shown to antagonize TGF $\beta$ signaling in FAP-like cells. Indeed, IFN $\gamma$ treatment reduces fibrosis in skeletal muscle after laceration injury, which is probably due to FAP apoptosis [77, 78].

Interleukin 1 beta (IL-1及) is part of the IL-1 superfamily (with IL-1 $\alpha$ and IL-33) and is mostly expressed by pro-inflammatory macrophages immediately after damage $[11,79]$. IL-1 $\beta$ receptors (IL-1R1 and IL-1R2) are not only expressed by macrophages but also in SCs and FAPs [68]. In vitro, stimulation of $\mathrm{C} 2 \mathrm{C} 12$ cells or primary myoblasts 


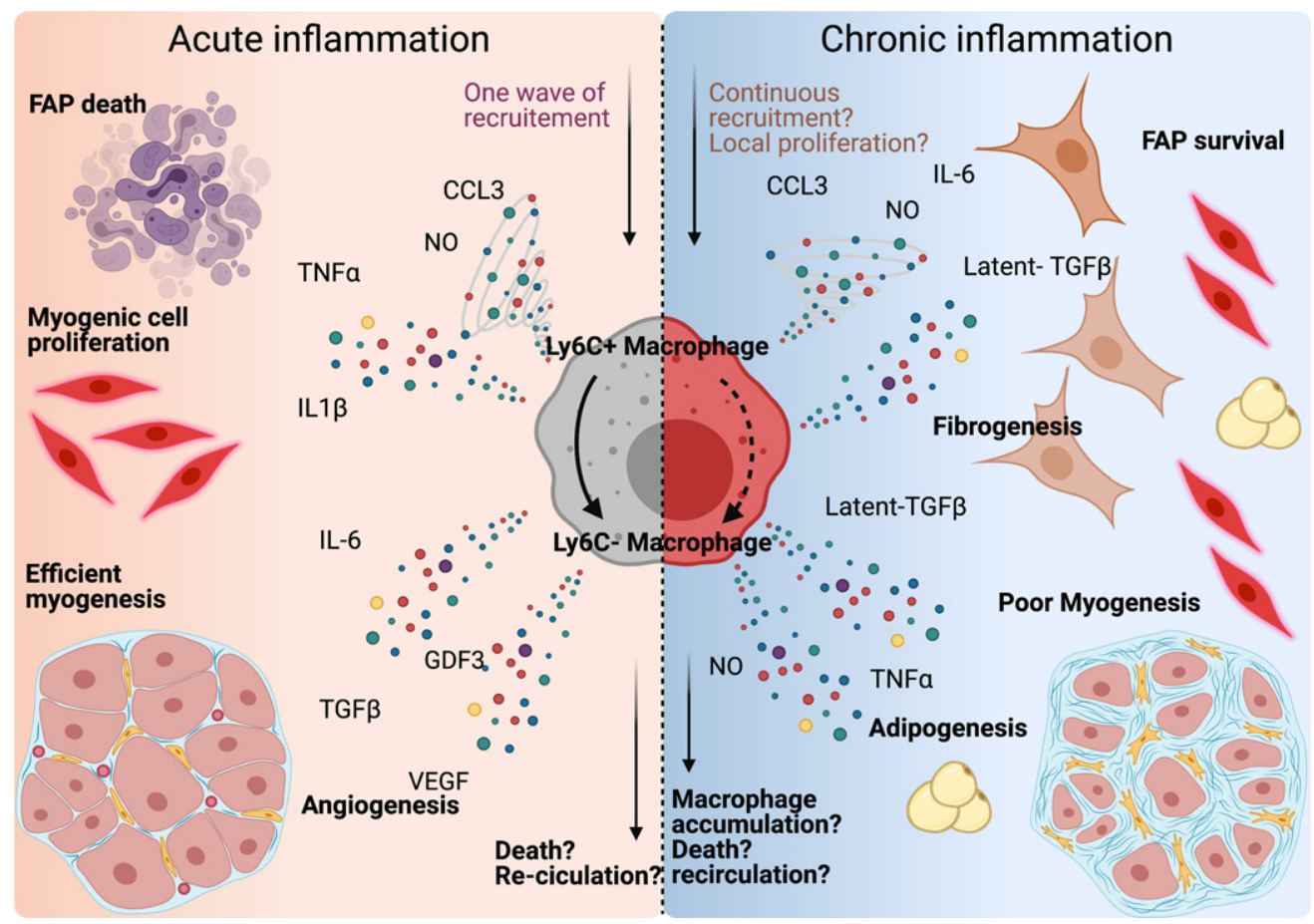

Fig. 2. Macrophages orchestrate muscle-resident cell behaviour during tissue repair. Left panel: after injury, Ly-6C+ macrophages secrete CCL3, NO, TNF $\alpha$ and IL-1 $\beta$, clear fibro-adipogenic progenitors (FAPs) from the tissue, and support myogenic cell proliferation. Once skewed to an anti-inflammatory profile, macrophage produce IL-6, GDF3, TGF $\beta$, and VEGF, which participate into the support of the myogenic program and myofiber growth. Macrophage content within the tissue returns to basal around 2 weeks after damage by either re-circulation or local apoptosis. Right panel: in case of repeated trauma, the number of macrophages present in the tissue rises, which could be due to continuous infiltration, or to local proliferation. Both Ly-6C+ and Ly-6C-macrophages are present within the tissue, which causes the accumulation of both pro- and anti-inflammatory cytokines in the damaged area. FAPs are activated, differentiate into fibroblast and adipocytes and myogenesis is delayed.

with IL-1 $\beta$ induces cell proliferation [79]. This effect is probably due to the activation of $\mathrm{NF} \kappa \mathrm{B}$ signaling, which is key for cell proliferation and survival. Of note, adding IL-1 $\beta$ blocking antibody in human myogenic cell culture with macrophage-conditioned medium induced myotube formation [52]. This suggests that IL-1 $\beta$ also has an anti-myogenic role, protecting from early differentiation.

Interleukin 10 (IL-10) is required for macrophages to acquire a pro-regenerative function [80, 81]. However, early delivery of IL-10 will prematurely induce macrophage skewing, delaying skeletal muscle regeneration [80]. This confirms that macrophage skewing needs to be precisely temporally regulated as faster resolution of inflammation does not always induce better recovery. This is supported by observations following the use of ice or anti-inflammatory compounds such as nonsteroidal anti-inflammatory drugs (NSAIDs) [2, 82]. Indeed, studies have reported that the use of NSAIDs 1) did not reduce soreness after exercise, 2) negatively affected SC fate, and 3) reduced muscle protein synthesis post exercise. However, in $>65$-year-old adults, as well as in old rats, NSAIDs help in the gain of muscle mass. Altogether, mouse, rat, and human studies report conflicted results in the use of NSAIDs, thus their use should be consciously done [83].

Interleukin 6(IL-6) production has been observed in almost all cells present in skeletal muscle (FAPs, endothelial cells, smooth muscle cells, myofibers, and various immune cells such as eosinophils and macrophages). Like TGF $\beta$ and TNF $\alpha$, IL- 6 has both pro and anti-inflammatory functions [84], making understanding its role in regeneration complicated. To note, IL-6 is produced at a high level after exercise, but the source seems to be myofibers rather than infiltrating immune cells [85]. However, the concentration of IL- 6 peaks at day 6 after acute injury, and delivery of IL-6 in vitro has interestingly no effect on proliferation of the myogenic cell line C2C12 [79]. However, as observed with IL-1 $\beta$, blocking IL-6 in human macrophage conditioned medium induces 
myotube formation in vitro, suggesting an anti-myogenic function of macrophage-derived IL-6 [52].

Interleukin 13 (IL-13) and Interleukin 4 (IL-4) are type 2 cytokines usually secreted by eosinophils, T cells, and Innate Lymphoid Cells (ILCs). Both have been described to induce macrophage skewing [86, 87]. To note, IL-4 treated FAPs support SC differentiation in vitro [86]. Plus, the IL-4/IL-13 axis also blocks FAP differentiation into adipocytes, allowing efficient regeneration [86]. In adipose tissue, it has been suggested that the IL-4/IL-13 axis is required for tissue resident mesenchymal stromal cells (FAPlike cells) to produce CCL11 (Eotaxin1) and attract eosinophils to maintain a type 2 inflammatory environment [87-89]. This chain of events has not been demonstrated in skeletal muscle, but represents a potential mechanism for eosinophil recruitment and the resolution of inflammation.

Nicotinamide phosphoribosyltransferase (NAMPT, also known as Visfatin or PBEF) is secreted by a specific population of macrophages during regeneration and acts on SCs via CCR5 to induce their proliferation [62]. In a zebrafish model, NAMPT+ macrophages appear to assume a pro-regenerative role similar to that observed in mouse and human, where they appear 2 days after injury and express $\arg 2, \mathrm{mmp} 13$, and mmp9 [62].

Transforming growth factor beta (TGFß) is a complex cytokine known to affect the behavior of most cells through disparate signaling pathways. The TGF $\beta$ superfamily is composed of 50 members, with TGF $\beta 1$ and myostatin being the most highly expressed in skeletal muscle [90]. One of the best known functions of TGF $\beta$ is its potent effect on fibrogenesis $[8,9,91]$. For example, TGF $\beta$ induces FAP survival (counteracting the IFN $\gamma / \mathrm{TNF} \alpha$ pro-apoptotic effect) and differentiation into myofibroblast [59]. TGF $\beta$ is also known for its inhibitory effect on myogenesis [92-95]. As TGF $\beta$ ligands (TGF $\beta 1,2$, and 3) are secreted by multiple sources, it is difficult to discern paracrine and autocrine function. Interestingly, macrophage-secreted GDF3, which is a ligand of the TGF $\beta$ superfamily, has been shown to promote SC commitment to myogenesis [60]. Lastly, TGF $\beta$ is known to be secreted in a non-active form (called latent TGF $\beta$ ), which is sequestered in the ECM in complex with latent TGF $\beta$ binding proteins (LTBP) [96]. Thus, its activity and action on SCs and FAPs can temporally differ from its secretion.

Tumor Necrosis Factor alpha (TNF $\alpha)$. TNF $\alpha$ is another complex cytokine, which can have differ- ent effects that are dependent upon its concentration. Interestingly, when secreted at high concentrations by inflammatory macrophages, it has anti-myogenic properties. However, when TNF $\alpha$ is secreted at low levels by anti-inflammatory macrophages, it instead functions as a pro-myogenic cytokine [52]. This differential effect is probably compounded by a globally changing cytokine milieu in the regenerative process. It would be interesting to study if the dual function of TNF $\alpha$ is only due to its concentration, or to its cooperation with other cytokines (e.g. IL-1 $\beta$ ).

Vascular endothelial growth factor (VEGF). While VEGF is mostly known for its pro-angiogenic functions, its effects on myogenic cell behavior have recently been explored [97, 98]. Indeed, inhibition of VEGF induces myotube formation in vitro, suggesting an anti-myogenic function of macrophagic VEGF [52]. However, Verma et al., showed that SC-derived VEGFA helps to maintaining the niche micro-environment and encourages their own quiescence [98]. Interestingly, quiescent SCs do not appear to express detectable levels of VEGF receptors $(K d r$ (VGFR2) or Flt1 (VGFR1)). Thus, further studies into how VEGFA acts on SC behavior is warranted.

\section{HISTOPATHOLOGY AND ANIMAL MODELS OF MUSCULAR DYSTROPHIES}

MDs are a heterogeneous group of inherited disorders characterized by progressive wasting and weakness of muscle tissue that compromises patient mobility, leading to wheelchair dependency. In severe cases, patients with MDs die prematurely due to respiratory and cardiac failure [99]. Many MDs are caused by mutations in the genes coding for proteins of the dystrophin-glycoprotein complex (DGC) or required for the correct assembly of the DGC. The main components of this multiprotein complex are dystrophin and sarcoglycan subunits. Structurally, the DGC links the F-actin cytoskeleton of myofibers to the ECM. The absence of even one protein of the DGC often causes the disassembly of the entire complex, causing sarcolemmal (the myofiber plasma membrane) fragility and leading to myofiber damage and necrosis that is aggravated by contractile activity [100-102]. Damaged myofibers are repaired or replaced by SCs, but as they share the same genetic mutation, the newly formed myofibers are destined for the same degenerative fate. Consequently, muscle tissue enters into a continuous cycle of degeneration and regeneration that 
results in chronic inflammation and substitution of contractile muscle tissue with adipose and fibrotic tissue. At the histological level, dystrophic muscle is characterized by necrotic myofibers, desynchronized centrally-nucleated regenerative myofibers, immune cell infiltration, and the presence of fatty/fibrotic lesions in place of muscle tissue [103].

The most common MD is the Duchenne muscular dystrophy (DMD), an X-linked autosomal recessive disease caused by a mutation in the $\sim 2.4 \mathrm{Mb}$ dystrophin gene that results in complete loss of the dystrophin protein and affects approximately 1 in $3,500-6,000$ boys $[104,105]$. The first signs of disease are usually observed around 2 to 3 years of age, followed by progressive muscle wasting, gradually leading to wheelchair use and eventual death caused by respiratory and cardiac complications [99, $106,107]$. In DMD $60 \%$ of dystrophin mutations are large insertions or deletions that lead to frameshift errors downstream, whereas approximately $40 \%$ are point mutations or small frameshift rearrangements [108]. Becker-type muscular dystrophy (BMD) is also caused by a mutation to the dystrophin gene, but one that permits the synthesis of an internally truncated and partially functional protein, leading to a milder phenotype in affected boys [99]. MDs are particularly difficult to treat due to the postmitotic nature of cardiac and skeletal muscle, as well as the abundancy of muscle tissue across the body. Different animal models are used to understand the development of the dystrophic disease as well as molecular and cellular pathways involved in this process [109]. Here are some of the main mouse models:

$\boldsymbol{m} \boldsymbol{d} \boldsymbol{x}$ mice: the mouse model for DMD is called $m d x$ and is the main animal model used to study MDs. The $m d x$ mutant came from a spontaneous mutation in a colony of C57BL/10ScSn mice, first reported in 1984 by Bulfield. Myofiber necrosis appears in the limbs of $m d x$ mice at 3 weeks of age and a first peak of inflammation and necrosis occurs at 4 weeks. From this point forward, the muscle enters a cycle of degeneration and regeneration. At 8 weeks of age, $80 \%$ of myofibers are centrally-nucleated and myofiber size is highly heterogeneous [110-113]. Due to the lack of the DCG, $m d x$ myofibers are fragile, and damage can be easily induced through muscle contraction (similar to eccentric exercise). Unlike human DMD muscles that are progressively replaced by fat and fibrosis, limb muscles of young $m d x$ mice develop only mild fibrosis and no fat infiltration, suggesting that $m d x$ muscles have a higher capacity for regeneration com- pared to human dystrophic muscle. At 12 months of life, $m d x$ muscle is still regenerative $[111,112]$ and it is not until 18 and 24 months of age that fibrosis and adipose infiltration are observed, respectively [110]. The only $m d x$ muscle that faithfully recapitulates human DMD progression is the diaphragm. In this tissue, the first histopathological muscle lesions appear at 1 month of life and over time myofibers are replaced by fibrotic tissue $[114,115]$. Thus, while human DMD patients and $m d x$ mice both lack dystrophin, mice do not progress to the same level of pathophysiological severity, which limits their use for modelling human DMD. Since the $m d x$ mouse model does not adhere to the general symptoms of the human disease, some variations of the mouse model have been generated in order to better mimic DMD pathology:

Micro-damage: a mechanical strategy entailing repeated daily microneedle stabs, inducing fibrosis and myofiber size heterogeneity 1 -week post-injury in the tibialis anterior of $m d x$ mice. Asynchronous regeneration is linked to appearance of fibrotic tissue and failed regeneration $[116,117]$.

$m d x$ :utrn+/- mouse model: a genetic strategy used to create $m d x$ models that develop fibrosis earlier. It is based on the hypothesis that some structural proteins, such as UTROPHIN could compensate the lack of dystrophin in $m d x$ mice. Double knockout $m d x$ :utrn $^{-1-}$ mice show severe progressive MD, leading to premature death, although haploinsufficiency of the utrn gene is enough to induce early fibrosis in limb muscles in $m d x$ mice $[118,119]$.

D2-mdx: another hypothesis advanced to explain histological differences between $m d x$ mice and DMD muscle was a higher regenerative capacity inherent to the murine genetic background. In fact, after several rounds of cardiotoxin injury, C57BL10 mouse strain muscles regenerate efficiently while muscles of DBA/2 mice display fibrosis and fat infiltration [120]. This impaired regeneration is due to a decrease in SC proliferation, leading to a decrease in myogenic cells available for fusion and consequently smaller regenerated myofibers. The most commonly used $m d x$ murine model is on the C57BL10 background, while $m d x$ mice backcrossed with the DBA/2 background (or D2- $m d x$ ) exhibit more rapidly progressing dystrophic pathology [120-122]. D2$m d x$ display muscular atrophy and an increase in fibrotic area in tibialis anterior, gastrocnemius and quadriceps muscles compared to $m d x$ mice $[120,121,123]$. 
$\boldsymbol{m} \boldsymbol{d} \boldsymbol{x}^{\text {betageo }}$ : Recently, Young et al., generated a model of $m d x$ with complete loss of dystrophin by introducing a disruption in the reading frame downstream of exon 63: $m d x^{\text {betageo }}$ [124]. These dystrophic mice do not express the full length Dp427 isoform of dystrophin but do express the truncated Dp71 isoform. The total absence of the long dystrophin isoform induces a decrease in myofiber size, and an increase of fibrosis and calcification in the tibialis anterior. Calcification was also observed in other limb muscles and in the heart of $m d x^{\text {betageo }}$ mice. Interestingly, high numbers of macrophages were found around calcified myofibers [124]. This model is often compared to the DMD-null mouse model that lack the full length of the dystrophin protein (both Dp71 and DP427 isoforms) [125, 126].

$\alpha$-sarcoglycan deficiency: the mouse model for $\alpha$-sarcoglycan deficiency (sgca $^{(-/-)}$mouse) was designed to model an existing sarcoglycan human mutation, found in patients of LGMD type 2D/R3 [132]. Necrotic myofibers are observed at 3 weeks of age and more than $70 \%$ of myofibers are centrallynucleated in limb muscles and diaphragm at 8 weeks. The $\operatorname{sgca}^{(-/-)}$mouse exhibits a decrease in muscle function and, importantly, fibrosis occurs earlier in limb muscles and the diaphragm [132-134]. So even while the genetic origin of the disease is different between $m d x$ and $\operatorname{sgca}^{(-/-)}$mice, the development of DM pathology in the latter more closely captures that observed in human MDs.

In $m d x$, $\operatorname{sgca}^{(-/-)}$, and DMD, a highly inflammatory environment (in terms of cell infiltration and cytokine detection) is observed compared to WT, non-damaged muscles [111, 115, 128, 134-137]. While macrophages are required and beneficial for efficient muscle regeneration after acute injury (see chapter above), chronic inflammation leads to tissue damage. In the case of skeletal muscle, the deleterious effect of macrophages during periods of chronic damage is hypothesized to be attributed to: 1) a sustained inflammatory environment that promotes muscle tissue damage, and 2) fibrosis induced by abnormal persistence of wound-healing macrophages. Indeed, in the last decades, many studies thoroughly investigated the phenotype and functions of macrophages in MDs.

\section{ROLE OF MACROPHAGES IN CHRONIC INJURY: FRIENDS OR FOES?}

Muscle regeneration following acute injury can be impaired by genetically or pharmacologically affect- ing macrophage's capacity to infiltrate the tissue [11, $57,58,138-140]$. However, in dystrophic muscle the decreased inflammation associated with modifying macrophage's infiltrative capacity often correlates with improved tissue functionality. In both human DMD, and mouse models like in $\mathrm{sgca}^{(-/-)}$and $m d x$, the number of macrophages correlate with expression of fibrotic markers [56].

Depletion of blood-circulating monocytes in young $m d x$ mice using an anti-F4/80 antibody reduces the number of damaged myofibers, presumably because it delays the peak of inflammation that normally occurs in $m d x$ mice at early time point [141] (Table 3). Preventing macrophage infiltration by deleting the TLR4 receptor also attenuates MD progression in 6 and 12-week-old $m d x$ mice by limiting muscle damage and fibrosis, while also limiting loss of force [142] (Table 3). Likewise, deleting the CCR2 receptor in $m d x$ mice $\left(m d x: \mathrm{CCR} 2^{-/}\right)$decreases macrophage infiltration in the diaphragm at 6 weeks of life. Interestingly, at 12 weeks of age, $m d x: \mathrm{CCR} 2^{-/-}$mice have the same number of intramuscular macrophages compared to $m d x$ control mice, suggesting a role for tissue-resident macrophages in disease progression. Furthermore, there are more CD206+ (pro-regenerative) macrophages and fewer iNOS+ (pro-inflammatory) macrophages in the diaphragm of $m d x: \mathrm{CCR} 2^{-1-}$ mice at 6 weeks of age. Again, this may be due to contribution of tissue-resident macrophages, which may not be able to efficiently acquire a pro-inflammatory phenotype. No difference in terms of histopathology is observed between $m d x$ and $m d x: \mathrm{CCR} 2^{-/-}$mice at 6 weeks of age, but at 12 weeks of age a decrease in the number of necrotic myofibers and area of fibrosis is observed in the diaphragm of double mutant mice. Functional improvement in the diaphragm is observed at both 6 weeks and 12 weeks of age [143] (Table 3).

Consistent with these results, the use of a pharmacological antagonist of CCR2/CCR5 receptor (CVC or cenicriviroc) in $m d x$ mice from 2- to 6-weeks of age decreased macrophage infiltration of the diaphragm in treated mice without any effect on myofiber necrosis and fibrosis. However, no changes in the ratio of CD206+ or iNOS+ macrophage were observed [144] (Table 3). Analysis of $m d x$ mouse pathology at 1 year shows that these animals approach a similar disease state to that of human DMD patients (force, regenerative capacity, central nuclei, muscle hypertrophy, and myofiber branching). Similarly, the early improvements observed in the diaphragm and quadri- 
Table 3

Depletion of monocyte/macrophage in mdx mouse model

\begin{tabular}{|c|c|c|}
\hline Mouse model & Result & References \\
\hline$m d x$ injected with anti-F4/80 antibody & - Improved soleus muscle at 1- and 4-weeks of age & {$[141]$} \\
\hline$m d x: T L R 4-K O$ & $\begin{array}{l}\text { - Improved TA and diaphragm muscle histopathology at 6- and 12-weeks } \\
\text { of age }\end{array}$ & [142] \\
\hline$m d x: C C R 2-K O$ & $\begin{array}{l}\text { - Improved diaphragm muscle histopathology and function at 6- and } \\
\text { 12-weeks of age } \\
\text { - No improvement of diaphragm muscle histopathology and function at } \\
\text { 6-months of age }\end{array}$ & {$[143,145]$} \\
\hline$m d x$ injected with CCR2/CCR5 antagonist & $\begin{array}{l}\text { - Decreased macrophage infiltration at 2- and 6-weeks of age with no effect } \\
\text { on diaphragm muscle histopathology } \\
\text { - No changes in macrophage polarization (iNOs/CD206 ratio) }\end{array}$ & [144] \\
\hline$m d x: C D 11 b-D T R$ & - Worsening TA muscle histopathology at 12 -weeks of age & {$[147]$} \\
\hline
\end{tabular}

ceps of $m d x: \mathrm{CCR} 2^{-/-}$is lost by 6 months of age in these animals [145]. As in the study by Mojumbar et al., the diminution of macrophage infiltration at an early time point (4 weeks of age) disappears by 14 weeks and 6 months [143, 145], It remains unclear whether the regression in histological and functional improvement is due to re-infiltration of macrophages or from an effect on their inflammatory profile and function.

When $m d x$ mice are crossed with a urokinase plasminogen activator (uPA) deficiency model the progeny exhibit an increase in the degenerative muscle phenotype, including increased fibrosis and decreased muscle function. This phenotype also correlates with a decrease in macrophage infiltration in the dystrophic muscle [146] (Table 3). Interestingly, the transplantation of WT-BM into the $m d x: \mathrm{uPA}^{-/-}$ mice increased macrophage infiltration in dystrophic muscle and reversed the deleterious effect of uPA knockout, suggesting a pro-regenerative role of infiltrating uPA-expressing macrophages within the dystrophic muscle. Of note, muscular regeneration after acute injury is also observed in $\mathrm{uPA}^{-/-}$mice and is rescued by WT BM transplantation as well [146]. Another study demonstrated that the depletion of macrophages in $m d x$ mice (using a mouse model expressing the Dipheteria Toxin Receptor under the $\mathrm{CD} 11 \mathrm{~b}$ promotor) compromises muscle regeneration at 12 weeks of age by promoting adipogenic fate in SCs [147].

In conclusion, the functional phenotype of macrophages and more specifically, their trophic function toward other cells within the muscle, impacts disease progression more than the overall number of macrophages present in dystrophic muscle, and this parameter should be taken in consideration when analyzing muscle histopathology (Table 3 ).

\section{Trophic functions of macrophages toward muscle homeostasis in mdx mice}

During healthy muscle regeneration, two functionally distinct populations of macrophages are observed in a temporally precise sequence. Together, these pro-inflammatory $\mathrm{Ly}-6 \mathrm{C}^{+}$and pro-regenerative Ly$6 \mathrm{C}^{-}$macrophages efficiently coordinate to help heal the damage and return the affected muscle tissue back to homeostasis. However, the situation becomes more complex in dystrophic muscles, where gauging the functional status of the macrophages within the affected tissue using simple markers such as Ly-6C may be less reliable (Fig. 1 and Tables 1 and 2). In fact, a recent work suggests that this method fails to accurately capture the nuances of macrophage transcriptional status within these situations [56]. During muscle regeneration, macrophages simultaneously express pro- and anti-inflammatory programs, and their function is ultimately determined by the balance of these programs $[17,54,56]$ (Fig. 1 and Table 1). Gene expression analyses of $\mathrm{Ly}-6 \mathrm{C}^{+}$and $\mathrm{Ly}-6 \mathrm{C}^{-}$ macrophages sorted from non-fibrotic and fibrotic dystrophic muscle ( $m d x$ and $\operatorname{sgca}^{(-/-)}$mice) show that the canonically pro-regenerative $\mathrm{Ly}-6 \mathrm{C}^{-}$population actually express high levels of pro-inflammatory markers, suggesting the presence of a mixed-function population of macrophages within dystrophic muscle [56]. Indeed, nearly 50\% of macrophages present in $m d x$ mice express both TNF $\alpha$ and TGF $\beta$ [59]. Future studies that incorporate single cell and spatial RNA-sequencing technologies allow us to better understand macrophage polarization and function in dystrophic muscles and particularly, how they interact with other cell types. Nevertheless, numerous studies have helped to identify general functions of macrophages in chronic muscle injury. 
Genetic ablation of IFN $\gamma$ in $m d x$ mice ( $m d x$ :IFN $\gamma$ $\mathrm{KO})$ does not affect macrophage infiltration in 4 and 12 month-old mice, but does lead to a decrease in iNOS production and reduced damaged myofibers in hindlimb muscles [148]. The loss of IFN $\gamma$ also increased Myodl and Myogenin expression, which are markers of proliferating and differentiating myoblasts whose expression is linked with regeneration. Indeed, $m d x$ :IFN $\gamma$-KO mice have more centrally-nucleated myofibers and exhibit improved muscle function, suggesting enhanced tissue repair [148].

Deletion of iNOS in $m d x$ mice ( $m d x$ :iNOS-KO) has no effect on macrophage infiltration, but decreases myofiber lysis [149]. In DMD and $m d x$ muscles, a local increase in $\mathrm{TNF} \alpha$ has been observed, and leads to the activation of $\mathrm{NF} \kappa \mathrm{B}$ signaling $[150,151]$. Consistently, $\mathrm{NF} \kappa \mathrm{B}$ activity increases in diaphragm, gastrocnemius and tibialis anterior of 5-week-old $m d x$ mice compared to WT mice. In $m d x$ mice, $\mathrm{NF} \kappa \mathrm{B}$ is present in nuclei of both regenerating myofibers and immune cells.

Macrophage-specific deletion of $\mathrm{NF} \kappa \mathrm{B}$ in $m d x$ mice decreases the number of necrotic myofibers and results in reduced expression of TNF $\alpha$ and IL$1 \beta$ in 4-week-old animals. Interestingly, the specific deletion of $\mathrm{NF} \kappa \mathrm{B}$ in myofibers stimulates muscle regeneration and leads to an increase in embryonic myosin heavy chain positive $\left(\mathrm{eMHC}^{+}\right)$myofibers. Furthermore, an increase in cells expressing Pax7 and MyoD is observed in 4-week-old $m d x-\mathrm{NF} \kappa \mathrm{B}$ $\mathrm{KO}$ mice, suggesting a negative role of $\mathrm{NF} \kappa \mathrm{B}$ on $\mathrm{SC}$ behaviour. Finally, pharmacological inhibition of IKK/NF $\kappa$ B pathway reduces muscle necrosis and improves muscle regeneration, supporting the notion that this pathway is active in several cell types present in dystrophic muscle which act synergistically to rescue myopathic progression [151].

Weekly intra-peritoneal injections of $\mathrm{TNF} \alpha-$ blocking antibodies in $m d x$ mice during the first 90 days of life decrease the number of necrotic myofibers and have a positive effect on treadmill running time. Unfortunately, neither the inflammatory profile, nor possible mechanisms of action were investigated in this study [152]. The use of antiIL-6 antibody on $m d x: \mathrm{utrn}^{-/-}$from 2 to 13 weeks of age, was shown to significantly improve skeletal muscle histopathology by reducing Creatine Kinase (CK) levels, fibrosis deposition, increasing regenerating myofiber size [153]. However, these effects were not seen in the diaphragm. Paradoxically, while IL-6 has been shown to participate to the DMD pathology
[154], the inflammatory response, quantified by q-RTPCR was unchanged [153]. Moreover, Kostek et al. treated $m d x$ mice with IL-6 blocking antibodies for 5 weeks with no functional or histological improvements, but rather an increase in their "inflammation score" (quantified by the number of mononuclear cells observed on muscle slides) [155].

In a related recent study, 4-month-old $m d x:$ utrn $^{+/-}$ mice were injected intra-peritoneally every 3 days, for 28 days, with blocking antibody against RANKL (receptor activator of nuclear factor $\mathrm{NF} \kappa \mathrm{B}$ ligand) [156]. While muscle damage and fibrosis were decreased, and associated with an increase in myofiber size, the number of infiltrated macrophages did not change after treatment. Nevertheless, a relative increase of $\mathrm{CD} 206^{+}$macrophages was observed in muscle of $m d x /$ utrn $^{+/-}$mice injected with RANKL blocking antibody [156]. Similarly, the frequency of $\mathrm{CD}^{206^{+}}$cells increased in muscles of $m d x$ :IFN $\gamma-\mathrm{KO}$ mice [148].

$M d x:$ IL-10-KO mice have elevated numbers of necrotic myofibers and perform poorly in treadmill performance tests at both 4 and 12 weeks of age, when compared to $m d x$ mice. These mice have a lower frequency of $\mathrm{CD}_{163}{ }^{+}$pro-regenerative macrophages in muscle, but quantification of total macrophage infiltration was not performed [81]. Thus, IL-10 secretion seems to be beneficial for dystrophic muscle.

Finally, the beneficial effect of depleting specific pro-inflammatory cytokines or signaling pathways in MD pathology could be due to the fact that dystrophic myofibers are more sensitive to oxidative stress [157, 158].

Overall, the above studies suggest that decreasing macrophage pro-inflammatory signals and pushing them to an anti-inflammatory phenotype could be beneficial for dystrophic muscle [156]. However, most studies have focused on the first few weeks of life in $m d x$ mice, which unlike human patients is known to peak in inflammation at 4-weeks of age $[141,159]$. Thus, further detailed studies and critical evaluation of these datasets will be required to assess the potential of macrophage modulation as a therapeutic option for MD patients.

\section{The role of macrophages in the formation of fibrosis in muscular dystrophies}

At steady state, muscle ECM is a three-dimensional network that represents around $5 \%$ of tissue volume. The ECM is primarily composed of collagen type I, with myofibers being surrounded by collagen 
IV [160]. ECM's function as a structural substrate capable of supporting muscle fibers, blood vessels, and nerves must not eclipse its critical role as a regulator of cell fate. For example, it has been demonstrated that Collagen V and VI are intimately linked to SC quiescence $[161,162]$. After muscle injury, ECM is degraded by inflammatory cells, which permits their infiltration into the damaged tissue, while concomitantly facilitating effective migration of SCs [163, 164]. Specifically, the ECM is degraded by matrix metalloproteinases (MMPs), secreted by inflammatory cells and damaged myofibers [165-167]. A transient partially degraded ECM participates in myoblast differentiation and provides a scaffold for regenerative myofibers [168]. As such, the balance between ECM degradation and production is important for efficient regeneration. Fibrosis, which is a characteristic feature of MD pathology, is caused by excessive accumulation of ECM components resulting from ECM over-production, a defect in its degradation, or both [168, 169]. Among the factors that promote ECM remodeling, TGF $\beta$ is believed to be the most important. TGF $\beta$ not only induces collagen I, connective tissue growth factor (CTGF/CCN2) and fibronectin expression by FAPs/ fibroblasts, but also inhibits MMP expression in fibroblasts through SMAD pathway activation [90, 170-172]. While macrophages and SCs do express some collagen proteins, FAPs are the primary source of ECM component secretion [162, 173, 174]. FAPs were identified in 2010 and are defined as SCA1/PDGFR $\alpha^{+}$, CD31/CD45/ $\alpha 7$ int $^{-}$cells. FAPs are located in the skeletal muscle interstitial space and proliferate upon injury $[8,9]$. In both in vitro and in vivo conditions, FAPs are capable of spontaneously differentiating into fibroblasts and adipocytes, but they do not differentiate into myogenic cells [8, $9,50]$. They stimulate myogenic differentiation in SCs, which once differentiated into myofibers, block FAP adipogenic differentiation [8, 175, 176]. In $m d x$ mice, the number of PDGFR $\alpha^{+}$cells positively correlates with fibrosis and addition of TGF $\beta 1$ to FAPs in vitro induces a dose-dependently increase in fibrotic markers (such as collagen I and CTGF $[8,9$, 59]), supporting the importance of this factor in fibrosis development. Importantly, the balance between proliferation and apoptosis of FAPs is directly determined by macrophage-derived TGF $\beta 1$

\section{The unforgettable TGF $\beta$}

During skeletal muscle regeneration, pro-inflammatory macrophages first secrete $\mathrm{TNF} \alpha$, which induces FAP apoptosis bringing their numbers back to pre-damage levels. Next, pro-regenerative macrophages secrete TGF $\beta$ to stimulate the survival of remaining FAPs and the production of a regenerative provisional matrix. Proper balance and coordinated expression of these cytokines is thus critical for reestablishment of the ECM [56, 59, 177] (Fig. 2). For more background on the role of FAPs in muscle homeostasis, we suggest the following reviews $[178,179]$.

In DMD patients, TGF $\beta 1$ is elevated in both blood plasma and muscle, and is correlated with fibrosis [91, 180, 181]. In addition, treatment of WT mice with recombinant TGF $\beta 1$ stimulates the expression of collagen I and induces muscle fibrosis independently of injury or disease [182]. It has been demonstrated that asynchronous myofiber damage and regeneration, such as that observed in DMD, directly induces fibrosis through the TGF $\beta 1$ pathway [117]. However, the induction of a fibrogenic program in FAPs is not the only way in which TGF $\beta 1$ can modulate muscle homeostasis. The binding of TGF $\beta 1$ and/or myostatin to their specific cell-surface receptors (TGFBR1/ALK5 and TGFBR2 dimer for TGF $\beta 1$; activin receptor types IIA and IIB dimer, or TGFBR1/ALK5 and ALK4 receptor dimer for myostatin) can lead to a decrease in the expression of the muscle fiber hypertrophic factor IGF-1 [93, 183].

TGF $\beta 1$ is expressed by multiple different cell types such as FAPs/fibroblasts and endothelial cells, but mainly by macrophages: over $75 \%$ of these cells in the $m d x$ diaphragm express TGF $\beta[90,171,184]$. One important feature of TGF $\beta 1$ signaling is that ligand gene expression may not directly lead to downstream signaling activation. This has been demonstrated in animal models where TGF $\beta$ expression levels do not correlate with the amount of fibrosis observed [185, 186]. Indeed, secreted TGF $\beta 1$ is often found bound to LTBP and is stabilized but kept inactive until LTBP cleavage [187]. Notably, DMD muscles exhibit elevated LTBP4, regulating TGF $\beta 1$ availability [188].

Treating $m d x$ mice with Nilotinib (which inhibits p38-like kinases downstream of TGF $\beta$ ) rescues the dystrophic phenotype by decreasing FAP numbers and the associated fibrosis [56, 59]. The dystrophic environment alters the effect of macrophages toward FAPs. Inflammatory macrophages (Ly$\left.6 \mathrm{C}^{+} \mathrm{CX} 3 \mathrm{CR} 1^{\text {low }}\right)$ isolated from fibrotic $m d x$ muscle have lost their ability to induce fibroblast apoptosis and instead stimulate collagen I expression [56]. This effect is reversed by anti-TGF $\beta$ antibody treatment. Moreover, inflammatory macrophages from fibrotic 
$m d x$ muscle express more LTBP4, which allows for more latent TGF $\beta 1$ to be stabilized within the ECM compared to non-fibrotic mdx muscle. In $m d x$ muscle, FAPs secrete MMP14 and BMP1 proteases to release TGF $\beta 1$ from LTBP4 [56].

Treatment of $m d x$ mice with the AMPK activating compound metformin (otherwise used for the treatment of type 2 diabetes) promotes proinflammatory to pro-regenerative macrophage phenotype skewing, reduces fibrosis, and improves muscle morphology [56]. In $m d x$ :IL-10-KO mice, macrophages increase their expression of proinflammatory cytokines and an increase in mature TGF $\beta$ and collagen I secretion within muscle tissue is observed [189]. Similarly, fibrinogen (a soluble protein released into the blood in response to stress which accumulates in $m d x$ and DMD muscles)-activated BMDMs treated with blocking IL-1 $\beta$ antibodies exhibit a decrease in $T g f b$ gene expression. On the other hand, mdx fibroblasts treated with conditioned medium of fibrinogen activated BMDM increases collagen I (Collal) expression, and this pro-fibrotic effect can be reverted with TGF $\beta 1$ blocking antibody [190]. Together, these studies demonstrate that the atypical pro-inflammatory macrophages found in dystrophic muscle not only act on myofiber damage and repair, but are also capable of directly inducing fibrosis. Thus, in dystrophic conditions, the dysregulation of macrophage phenotype induces a vicious cycle between macrophage LTBP4-TGF $\beta$ expression, FAP survival and ECM component expression that leads to fibrosis.

It should be noted that the effects of TGF $\beta$ are not limited to FAP/fibroblasts. SCs and endothelial cells also express receptors for this molecule. In vitro treatment of SCs and endothelial cells with TGF $\beta$ results in decreased myotube and angiotube formation and is associated with an increase in fibrotic gene expression [174]. By using specific endothelial cell and SC tracking mice, this phenomenon has been replicated in vivo in 6-month-old $m d x$ mice. Specifically, approximately $12 \%$ of SCs downregulated a myogenic fate marker (loss of $\alpha 7$-integrin) and showed elevated Collal and fibronectin extra domain A $(E d a-F n l)$ expression. Similarly, $30 \%$ of the original endothelial cell population reduced CD31 expression, with a concomitant increase in Collal and Eda-Fnl [174]. Within dystrophic muscle, infiltrating macrophages also become pro-fibrotic expressing more collagen I and less CD45. These "fibrotic" SCs, endothelial cells and macrophages represent only $1-2 \%$ of the total fibrogenic population, and while they may not have a major impact on fibrosis per se, they may no longer be capable of participating in muscle and vessels formation. Indeed, myogenic cells, endothelial cells and macrophages must communicate for effective muscle regeneration and it has been observed that $m d x$ mice also exhibit impaired vessels formation and functional vascular defects $[98,191,192]$.

\section{Other proteins expressed by macrophages that modulate MD progression}

Several studies have pointed out additional proteins expressed by macrophages that exacerbate or attenuate muscular dystrophy progression.

MMPs are expressed by macrophages and support cell migration to injured tissue. MMP expression is increased in dystrophic mouse muscle. $m d x$ :MMP9KO mice not only show reduced macrophage infiltration, but also a switch toward a pro-regenerative macrophage phenotype, characterized by an increase in $\mathrm{CD}_{206}{ }^{+}$. Moreover, $m d x$ :MMP9-KO mouse muscle structure is improved and correlates with a decrease in serum Creatine Kinase levels, which is a marker of myofiber damage [193, 194]. Lastly, depletion of MMP9 increases SC proliferation and improves the engraftment potential of myoblasts in recipient mouse muscle pre-injured with cardiotoxin [194]. However, MMPs also play a beneficial role in the regenerative process that follows acute damage. For example, MMP-10 is expressed by macrophages and endothelial cells in response to injury, and its deletion increases macrophage infiltration, myofiber necrosis and interstitial fibrosis [195]. Batimastat is a broad spectrum MMP inhibitor that acts on MMP1, MMP-2, MMP-3, MMP-7, MMP-8, MMP-9, and MMP-14 activity by mimicking the site in the collagen substrate that is cleaved by MMPs [196, 197]. Treatment of $m d x$ mice with Batimastat increases the levels of DGC protein components, improves muscle structure and force, and reduces the number of damaged myofibers. A decrease in the number of infiltrating macrophages, as well as in fibrosis (decreased Col3al expression and smaller proportion of Picrosirius red stained area) was also observed [198].

IGF-1 induces muscle hypertrophy in mice and rats by promoting SC proliferation and myofiber anabolism [199-201]. Treating $m d x$ mice with IGF1 for 8 weeks, starting from 5-6 weeks of age, improves fatigue resistance in EDL and soleus muscles [202]. Similarly, overexpression of IGF-1 in $m d x$ mice induces muscle hypertrophy, increases muscle force and reduces fibrosis [71]. Depleting macrophages in injured muscle significant 


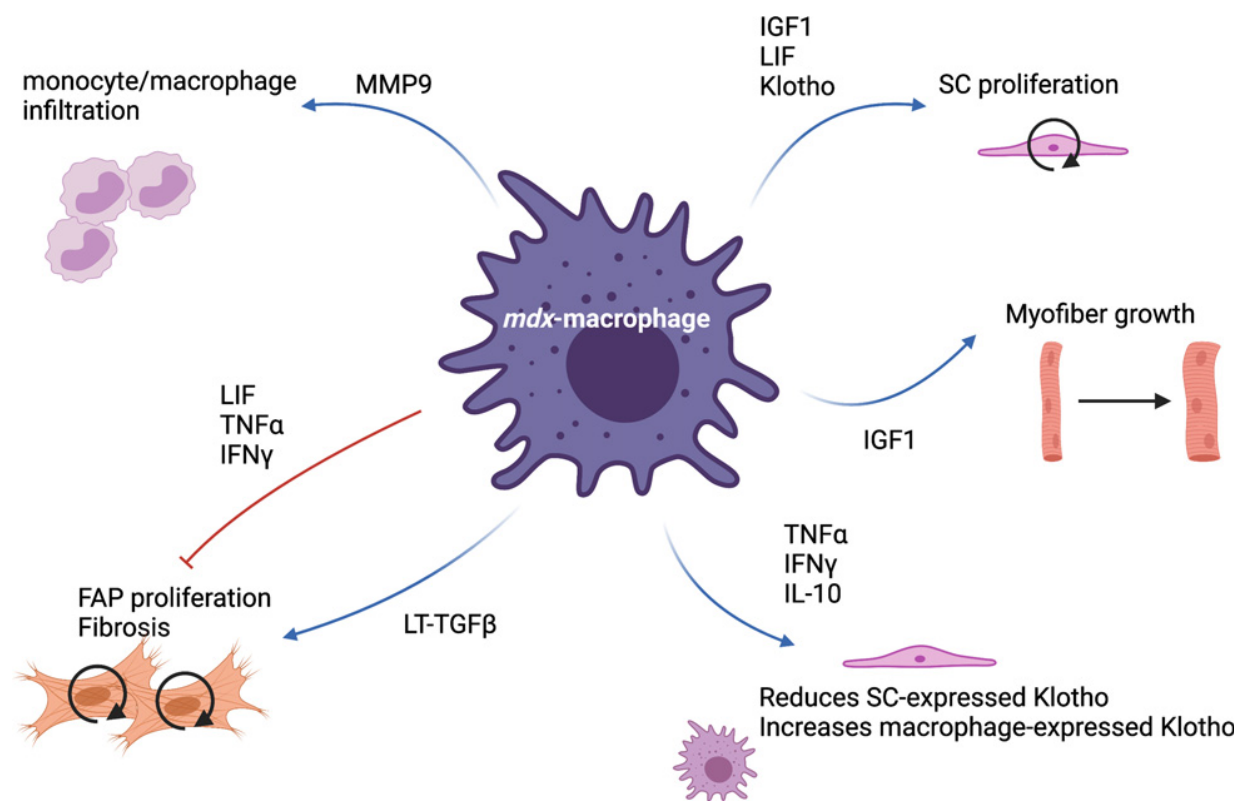

Fig. 3. mdx-macrophage specific functions. Via the production of many cytokines and proteins, macrophages present in mdx muscle are able to simultaneously stimulate and inhibit various cellular processes such as monocyte infiltration, satellite cell (SC) proliferation, myofiber growth, fibro-adipogenic progenitor (FAP) proliferation and differentiation.

decreases IGF-1 levels, showing that macrophages are a primary source of IGF-1 within this context. Moreover, deletion of macrophage-specific deletion of IGF-1, as in the LysM ${ }^{\mathrm{CRE}}$ mouse strain, induces a defect in pro-regenerative phenotype acquisition and, consequently, delayed muscle regeneration [73]. Overexpression of IGF-1 in myofibers down-regulates the expression of pro-inflammatory cytokines and rapidly stimulates tissue remodeling [203]. This suggests an autocrine effect of IGF-1 on macrophages and a paracrine effect on myogenic cells that appears beneficial within the context of MD.

Leukemia inhibitory factor (LIF) is expressed by myoblasts and macrophages and has a positive effect on SC proliferation [204, 205]. In $m d x$ mice, treatment with LIF decreases fibrosis, stimulates muscle regeneration, and increases myofiber size [206, 207]. In 2019, Welc et al., studied the effect of LIF overexpression in macrophages using a transgene controlled by the human CD11b promoter [208]. 1-12-monthold $m d x$ mice overexpressing LIF in CD11 $\mathrm{b}^{+}$cells showed a reduction in collagen deposits in TA and diaphragm muscle. Bone marrow transplantation (BMT) of transgenic $\mathrm{CD}_{11} \mathrm{~b}^{+} / \mathrm{LIF}^{+}$cells into 1-month-old $m d x$ mice decreases macrophage infiltration with a decreased collagen I, IV and V deposit area in tibialis anterior muscles 4 months after transplantation. Interestingly, TGF $\beta$ secretion by macrophages is decreased in the presence of LIF, which also decreases FAP numbers. While TGF $\beta$ induces $\mathrm{CTGF} / \mathrm{CCN} 2$ expression in the $\mathrm{C} 2 \mathrm{C} 12$ cell line, co-stimulation with LIF abrogates this increase after $24 \mathrm{~h}$ in culture. In vivo, while SCs from LIF $\mathrm{BMT} / m d x$ express less ECM related genes, mice do not present any changes in their histopathology [208], consistent with the notion that SCs do not play a major role in collagen deposition.

Klotho is a transmembrane protein that can be cleaved and released as a hormone, or alternatively expressed in a truncated form capable of being secreted [209, 210]. It modulates multiple signaling pathways, including FGFs, IGF1, TGF $\beta$ and Wnt [211]. At 2 weeks of age, $m d x$ mice display no difference in Klotho expression compared to WT mice. As inflammation peaks later during disease progression, Klotho expression drops, remaining low until at least 3 months of age. The overexpression of Klotho in $m d x$ mice decreases fibrosis, increases myofiber size at 24 months, and increases treadmill running time [212]. Interestingly, it has been demonstrated that Klotho signaling is suppressed by TNF $\alpha$ in the kidney [213]. Injection of recombinant Klotho protein decreases pro-inflammatory signals in both kidney and heart tissue $[214,215]$. The increase of TNF $\alpha$ and IFN $\gamma$ observed in $m d x$ muscles coincides with a decrease in Klotho [216]. In vitro TNF $\alpha$ treatment decreases 
Klotho expression in $\mathrm{C} 2 \mathrm{C} 12$ myotubes but activates its expression in macrophages. This phenomenon is also observed in the presence of IL-10 [216]. Of note, BMT of cells overexpressing Klotho into $m d x$ mice hosts increases $\mathrm{Pax}^{+}$SCs and myofiber size. Conditioned media co-culture experiments demonstrate that overexpression of Klotho by macrophages directly stimulates proliferation of SCs [216]. Rescue of Klotho expression by macrophages in $m d x$ mice improves MD histopathology by acting on myogenic cell proliferation [216].

Osteopontin (OPN) is up-regulated in both DMD patients and in $m d x$ mice. OPN, also known as Secreted Phosphoprotein 1 (SSP1) has been described as an upstream activator of $\mathrm{NF} \kappa \mathrm{B}$ signaling [217, 218]. Depletion of OPN in $m d x$ mice does not modify the total number of infiltrated macrophages but skews their phenotype to a less inflammatory profile (from iNOS ${ }^{+}$to $\mathrm{CD} 206^{+} / \mathrm{CD} 163^{+}$). Lack of $^{-}$ OPN in $m d x$ mice increases LIF, IGF-1 and UPA, and is associated with increased muscle mass, myofiber diameter, and improvement in muscle function [219]. OPN affects both immune and myogenic cells, but it is not clear which cell is responsible for its secretion, or whether its effect on muscle tissue is direct or indirect.

\section{TREATMENT OF MUSCULAR DYSTROPHIES: WHAT ABOUT MACROPHAGES?}

Excessive inflammation within dystrophic muscle is demonstrably more deleterious than beneficial. The only treatment that has shown a delay in disease progression is the use of glucocorticoids. Unfortunately, these potent anti-inflammatory drugs have significant side effects. Prednisone, one of the most widely used glucocorticoids, decreases inflammation and delays the progression of DMD, prolonging ambulation and modestly improving muscle strength and cardiopulmonary function. Side effects include bone fragility, weight gain, mood changes, and even muscle weakness [220-224]. Glucocorticoids stimulate the AKT1/FOXO1 pathway, which decreases protein synthesis and increases protein catabolism and is responsible for the seemingly contradictory muscle weakness and atrophy observed in patients treated with this drug [225]. Another potent glucocorticoid is Dexamethasone, but side effects are severe, making it an unappealing candidate for long-term treatment. Deflazacort is a less potent glucocorti- coid that has a similar effect to prednisone but with a reduced number of side effects [224, 226]. In the end, a combination of the different drugs seems the most appropriate way to delay MD progression [227]. The main concern stays the poor knowledge of long-term effects. For example, $m d x$ mice treated with prednisone for 50 days showed an improvement in early disease progression, which was subsequently lost when treatment was continued to 100 or 150 days [221]. In addition, whether the effects of corticosteroids are mainly through abatement of inflammation or though one of the other pleiotropic effects of these compounds is not yet clear.

Therapeutic approaches that harness macrophages are beginning to emerge. 24 hours after an acute ischemia/reperfusion injury, intra-muscular injection of pro-inflammatory macrophages has been shown to improve muscle regeneration, characterized by increased muscle force, myofiber diameter and by decreasing collagen deposition at 14 days postreperfusion [228]. At 5 and 7 days after reperfusion, a decrease in damaged muscle area is observed (probably via improved removal of dead cells). While the total number of macrophages was unchanged between control and the macrophage-injected muscles, an increase in the number of $\mathrm{CD} 206^{+}$macrophages was observed 5 days post-perfusion in the macrophage-injected muscle, demonstrating that the injected pro-inflammatory macrophages switched toward a pro-regenerative phenotype within the treated muscle [228]. Injection of human macrophages into damaged muscle of immuno-suppressed mice, together with human myoblasts, improved myoblast proliferation and led to better host cell integration within the myofibers [229]. As observed in mice, five days after their injection pro-inflammatory human macrophages expressed anti-inflammatory markers, further demonstrating their capacity to locally change phenotype during progression of muscle regeneration [229]. Of note, one of the main causes of failure of cell therapy for MDs is the poor survival and migration capacity of SCs and myoblasts after intramuscular injection. Co-injection of BMDM and SCs into $m d x$ muscle increases their proliferation, survival and migration [51]. Thus, "non-dystrophic" macrophages seem to support injected myoblasts in their regeneration of muscle tissue. Modification of macrophage phenotype could be beneficial to dystrophic muscle not only because macrophages act negatively on fibrogenic cells within the progression of MD, but also because of the evidence supporting their use in these cell therapies. Interestingly, 
Novak et al. demonstrated that myoblasts are not the only cells capable of delivering phosphorodiamidate morpholino oligomers to myofibers, and that macrophages are also potent releasers of these therapeutics, making them an attractive candidate for in situ delivery to myoblasts and myofibers [230].

\section{CONCLUSION}

Macrophages have been studied for decades and most of their functions are now understood. Indeed, their role beyond infection response, specifically as tissue resident cells involved in the remodelling of tissues (development, regeneration and repair) are well understood within the research community. However, the manipulation of their inflammatory state in order to direct their trophic functions toward tissueresident cells is far from being defined. MDs, and especially DMD are multifactorial diseases where necrosis, chronic inflammation, defects in angiogenesis, fibrofatty infiltration, and tissue remodelling occur asynchronously within the tissue. The defect in macrophage function in these diseases could be one of the reasons for poor outcome of cell and gene therapies. It is therefore important that further efforts be made to safely manipulate macrophage dynamics so that they might be used to therapeutic effect as part of a MD rescue approach. Today, single cell technology such as CITE-seq (Cellular Indexing of Transcriptomes and Epitopes by Sequencing) should allow the community to link macrophage function, polarization state and gene expression, to find appropriate therapeutic gene and protein targets. We imagine a future where "re-booting" or resynchronizing the inflammatory system would allow improvements to the muscle repair cycle, by delaying fibrosis apparition, and the loss of muscle function; or as synergistic tools used alongside gene and cell therapies to improve their efficacy.

\section{ACKNOWLEDGMENTS}

The authors would like to thank Dr. Morten Ritso and Mark Hamer for their helpful suggestions. Figures were created using BioRender.com

\section{AUTHORS' CONTRIBUTIONS}

M.S. and M.T. drafted the review. G.M and F.M.V.R. revised and reviewed the manuscript. All authors read and approved the final manuscript.

\section{FUNDING}

The authors were supported by European Community (ERCStG2011, RegeneratioNfix 280611) and the Association Française contre les Myopathies (AFM, 20002) to MS and GM, by Fondation pour la Recherche Médicale (FRM, 40248), by the European Molecular Biology Organization (EMBO, ALTF 115-2016), by the French Association Française contre les myopathies (AFM, 22576), and by Michael Smith Foundation for Health Research (MSFHR, 18351) to M.T.; and by the Canadian Institutes of Health Research (CIHR-FDN-159908) to F.M.V.R.

\section{COMPETING INTERESTS}

The authors declare that they have no competing financial interests. The funding agencies had no role in the review's design, the decision to publish, or preparation of the manuscript.

\section{REFERENCES}

[1] Theret M, Mounier R, Rossi F. The origins and noncanonical functions of macrophages in development and regeneration. Dev. 2019;

[2] Chazaud B. Inflammation and Skeletal Muscle Regeneration: Leave It to the Macrophages! Trends in Immunology. 2020.

[3] Gordon S. Elie Metchnikoff, the Man and the Myth. Vol. 8, Journal of Innate Immunity. 2016.

[4] Mauro A. Satellite cell of skeletal muscle fibers. J Biophys Biochem Cytol. 1961;

[5] Almada AE, Wagers AJ. Molecular circuitry of stem cell fate in skeletal muscle regeneration, ageing and disease. Nature Reviews Molecular Cell Biology. 2016.

[6] Wang YX, Rudnicki MA. Satellite cells, the engines of muscle repair. Vol. 13, Nature Reviews Molecular Cell Biology. 2012. p. 127-33.

[7] Cattaneo P, Mukherjee D, Spinozzi S, Zhang L, Larcher V, Stallcup WB, et al. Parallel Lineage-Tracing Studies Establish Fibroblasts as the Prevailing In Vivo Adipocyte Progenitor. Cell Rep. 2020;30(2):571-582.e2.

[8] Joe AWB, Yi L, Natarajan A, Le Grand F, So L, Wang $\mathrm{J}$, et al. Muscle injury activates resident fibro/adipogenic progenitors that facilitate myogenesis. Nat Cell Biol. 2010;

[9] Uezumi A, Fukada SI, Yamamoto N, Takeda S, Tsuchida K. Mesenchymal progenitors distinct from satellite cells contribute to ectopic fat cell formation in skeletal muscle. Nat Cell Biol. 2010;

[10] Roberts EW, Deonarine A, Jones JO, Denton AE, Feig C, Lyons SK, et al. Depletion of stromal cells expressing fibroblast activation protein- $\alpha$ from skeletal muscle and bone marrow results in cachexia and anemia. J Exp Med. 2013;

[11] Arnold L, Henry A, Poron F, Baba-Amer Y, Van Rooijen $\mathrm{N}$, Plonquet $\mathrm{A}$, et al. Inflammatory monocytes recruited after skeletal muscle injury switch into antiinflammatory macrophages to support myogenesis. J Exp Med. 2007;204(5):1057-69. 
[12] McLennan IS. Degenerating and regenerating skeletal muscles contain several subpopulations of macrophages with distinct spatial and temporal distributions. J Anat. 1996;188 (Pt 1.

[13] Pimorady-Esfahani A, Grounds MD, McMenamin PG. Macrophages and dendritic cells in normal and regenerating murine skeletal muscle. Muscle Nerve. 1997;20(2): 158-66.

[14] Summan M, Warren GL, Mercer RR, Chapman R, Hulderman T, Van Rooijen N, et al. Macrophages and skeletal muscle regeneration: A clodronate-containing liposome depletion study. Am J Physiol - Regul Integr Comp Physiol. 2006;290(6).

[15] Shireman PK, Contreras-Shannon V, Ochoa O, Karia BP, Michalek JE, McManus LM. MCP-1 deficiency causes altered inflammation with impaired skeletal muscle regeneration. J Leukoc Biol. 2007;81(3).

[16] Tidball JG, Wehling-Henricks M. Macrophages promote muscle membrane repair and muscle fibre growth and regeneration during modified muscle loading in mice in vivo. J Physiol. 2007;578(1).

[17] Mounier R, Théret M, Arnold L, Cuvellier S, Bultot $\mathrm{L}$, Göransson $\mathrm{O}$, et al. AMPK $\alpha 1$ regulates macrophage skewing at the time of resolution of inflammation during skeletal muscle regeneration. Cell Metab. 2013;

[18] Hardy D, Besnard A, Latil M, Jouvion G, Briand D, Thépenier C, et al. Comparative study of injury models for studying muscle regeneration in mice. PLoS One. 2016;

[19] Orecchioni M, Ghosheh Y, Pramod AB, Ley K. Macrophage polarization: Different gene signatures in M1(Lps+) vs. Classically and M2(LPS-) vs. Alternatively activated macrophages. Vol. 10, Frontiers in Immunology. 2019.

[20] Italiani P, Boraschi D. From monocytes to M1/M2 macrophages: Phenotypical vs. functional differentiation. Vol. 5, Frontiers in Immunology. 2014.

[21] Martinez FO, Sica A, Mantovani A, Locati M. Macrophage activation and polarization. Front Biosci. 2008;13: 453-61.

[22] Wang L xun, Zhang S xi, Wu H juan, Rong X lu, Guo $\mathrm{J}$. M2b macrophage polarization and its roles in diseases. Vol. 106, Journal of Leukocyte Biology. 2019.

[23] Pinhal-enfield G, Ramanathan M, Hasko G, Vogel SN, Salzman AL, Boons G, et al. An Angiogenic Switch in Macrophages Involving and Adenosine A 2A Receptors. Public Health. 2003;163(2).

[24] Ferrante CJ, Leibovich SJ. Regulation of Macrophage Polarization and Wound Healing. Adv Wound Care. 2012;1(1).

[25] Honda H, Kimura H, Rostami A. Demonstration and phenotypic characterization of resident macrophages in rat skeletal muscle. Immunology. 1990;70(2):272-7.

[26] Brigitte M, Schilte C, Plonquet A, Baba-Amer Y, Henri A, Charlier $\mathrm{C}$, et al. Muscle resident macrophages control the immune cell reaction in a mouse model of notexin-induced myoinjury. Arthritis Rheum. 2010;

[27] Ginhoux F, Guilliams M. Tissue-Resident Macrophage Ontogeny and Homeostasis. Immunity. 2016.

[28] Murray PJ, Wynn TA. Protective and pathogenic functions of macrophage subsets. Nature Reviews Immunology. 2011.

[29] Linehan E, Fitzgerald D. Ageing and the immune system: focus on macrophages. Eur J Microbiol Immunol. 2015;

[30] Gautier EL, Yvan-Charvet L. Understanding macrophage diversity at the ontogenic and transcriptomic levels. Immunol Rev. 2014;
[31] Wang X, Sathe AA, Smith GR, Ruf-Zamojski F, Nair V, Lavine KJ, et al. Heterogeneous origins and functions of mouse skeletal muscle-resident macrophages. Proc Natl Acad Sci U S A. 2020;117(34).

[32] Yona S, Kim K-W, Wolf Y, Mildner A, Varol D, Breker $\mathrm{M}$, et al. Fate mapping reveals origins and dynamics of monocytes and tissue macrophages under homeostasis. Immunity. 2013;38(1):79-91.

[33] Epelman S, Lavine KJ, Randolph GJ. Origin and functions of tissue macrophages. Immunity. 2014;41(1):21-35.

[34] Epelman S, Lavine KJ, Beaudin AE, Sojka DK, Carrero JA, Calderon B, et al. Embryonic and adult-derived resident cardiac macrophages are maintained through distinct mechanisms at steady state and during inflammation. Immunity. 2014;40(1):91-104.

[35] Chakarov S, Lim HY, Tan L, Lim SY, See P, Lum J, et al. Two distinct interstitial macrophage populations coexist across tissues in specific subtissular niches. Science (80-). 2019;363(6432).

[36] Dick SA, Macklin JA, Nejat S, Momen A, ClementeCasares X, Althagafi MG, et al. Self-renewing resident cardiac macrophages limit adverse remodeling following myocardial infarction. Nat Immunol. 2019;

[37] Hulsmans M, Clauss S, Xiao L, Aguirre AD, King KR, Hanley A, et al. Macrophages Facilitate Electrical Conduction in the Heart. Cell. 2017;169(3):510-522.e20.

[38] Geissmann F, Jung S, Littman DR. Blood monocytes consist of two principal subsets with distinct migratory properties. Immunity. 2003;19(1):71-82.

[39] Auffray C, Fogg D, Narni-Mancinelli E. CX3CR1+ CD115+ CD135+ common macrophage/DC precursors and the role of.... J.... 2009;

[40] Martinez CO, McHale MJ, Wells JT, Ochoa O, Michalek JE, McManus LM, et al. Regulation of skeletal muscle regeneration by CCR2-activating chemokines is directly related to macrophage recruitment. Am J Physiol - Regul Integr Comp Physiol. 2010;

[41] Ochoa O, Sun D, Reyes-Reyna SM, Waite LL, Michalek JE, McManus LM, et al. Delayed angiogenesis and VEGF production in CCR2-/- mice during impaired skeletal muscle regeneration. Am J Physiol - Regul Integr Comp Physiol. 2007;

[42] Contreras-Shannon V, Ochoa O, Reyes-Reyna SM, Sun D, Michalek JE, Kuziel WA, et al. Fat accumulation with altered inflammation and regeneration in skeletal muscle of CCR2-/- mice following ischemic injury. Am J Physiol - Cell Physiol. 2007;

[43] Lu H, Huang D, Ransohoff RM, Zhou L. Acute skeletal muscle injury: CCL2 expression by both monocytes and injured muscle is required for repair. FASEB J. 2011;

[44] Warren GL, Hulderman T, Mishra D, Gao X, Millecchia L, O'Farrell L, et al. Chemokine receptor CCR2 involvement in skeletal muscle regeneration. FASEB J Off Publ Fed Am Soc Exp Biol. 2005;19(3):413-5.

[45] Kaikita K, Hayasaki T, Okuma T, Kuziel WA, Ogawa $\mathrm{H}$, Takeya M. Targeted deletion of CC chemokine receptor 2 attenuates left ventricular remodeling after experimental myocardial infarction. Am J Pathol. 2004; $165(2)$.

[46] Okuma T, Terasaki Y, Kaikita K, Kobayashi H, Kuziel WA, Kawasuji M, et al. C-C chemokine receptor 2 (CCR2) deficiency improves bleomycin-induced pulmonary fibrosis by attenuation of both macrophage infiltration and production of macrophage-derived matrix metalloproteinases. J Pathol. 2004;204(5). 
[47] Lu B, Rutledge BJ, Gu L, Fiorillo J, Lukacs NW, Kunkel $\mathrm{SL}$, et al. Abnormalities in monocyte recruitment and cytokine expression in monocyte chemoattractant protein 1-deficient mice. J Exp Med. 1998;187(4):601-8.

[48] Chazaud B, Sonnet C, Lafuste P, Bassez G, Rimaniol AC, Poron F, et al. Satellite cells attract monocytes and use macrophages as a support to escape apoptosis and enhance muscle growth. J Cell Biol. 2003;163(5):1133-43.

[49] Wosczyna MN, Konishi CT, Perez Carbajal EE, Wang TT, Walsh RA, Gan Q, et al. Mesenchymal Stromal Cells Are Required for Regeneration and Homeostatic Maintenance of Skeletal Muscle. Cell Rep. 2019;

[50] Scott RW, Arostegui M, Schweitzer R, Rossi FMV, Underhill TM. Hic1 Defines Quiescent Mesenchymal Progenitor Subpopulations with Distinct Functions and Fates in Skeletal Muscle Regeneration. Cell Stem Cell. 2019;25(6):797-813.e9.

[51] Lesault PF, Theret M, Magnan M, Cuvellier S, Niu Y, Gherardi RK, et al. Macrophages Improve Survival, Proliferation and Migration of Engrafted Myogenic Precursor Cells into MDX Skeletal Muscle. PLoS One. 2012; $7(10)$.

[52] Saclier M, Cuvellier S, Magnan M, Mounier R, Chazaud B. Monocyte/macrophage interactions with myogenic precursor cells during skeletal muscle regeneration. FEBS J. 2013;280(17):4118-30.

[53] Varga T, Mounier R, Gogolak P, Poliska S, Chazaud B, Nagy L. Tissue LyC6- macrophages are generated in the absence of circulating LyC6- monocytes and Nur77 in a model of muscle regeneration. J Immunol. 2013;191(11): 5695-701.

[54] Varga T, Mounier R, Horvath A, Cuvellier S, Dumont F, Poliska S, et al. Highly Dynamic Transcriptional Signature of Distinct Macrophage Subsets during Sterile Inflammation, Resolution, and Tissue Repair. J Immunol. 2016;196(11):4771-82.

[55] Hanna RN, Carlin LM, Hubbeling HG, Nackiewicz D, Green AM, Punt JA, et al. The transcription factor NR4A1 (Nur77) controls bone marrow differentiation and the survival of Ly6C- monocytes. Nat Immunol. 2011;12(8).

[56] Juban G, Saclier M, Yacoub-Youssef H, Kernou A, Arnold L, Boisson C, et al. AMPK Activation Regulates LTBP4Dependent TGF- $\beta 1$ Secretion by Pro-inflammatory Macrophages and Controls Fibrosis in Duchenne Muscular Dystrophy. Cell Rep. 2018;25(8):2163-76.e6.

[57] Lu H, Huang D, Ransohoff RM, Zhou L. Acute skeletal muscle injury: CCL2 expression by both monocytes and injured muscle is required for repair. FASEB J. 2011;25(10):3344-55.

[58] Lu H, Huang D, Saederup N, Charo IF, Ransohoff RM, Zhou L. Macrophages recruited via CCR2 produce insulin-like growth factor-1 to repair acute skeletal muscle injury. FASEB J. 2011;

[59] Lemos DR, Babaeijandaghi F, Low M, Chang CK, Lee ST, Fiore D, et al. Nilotinib reduces muscle fibrosis in chronic muscle injury by promoting TNF-mediated apoptosis of fibro/adipogenic progenitors. Nat Med. 2015;21(7): 786-94.

[60] Varga T, Mounier R, Patsalos A, Gogolak P, Peloquin M, Horvath A, et al. Macrophage PPARgamma, a Lipid Activated Transcription Factor Controls the Growth Factor GDF3 and Skeletal Muscle Regeneration. Immunity. 2016;45(5):1038-51.

[61] McArthur S, Juban G, Gobbetti T, Desgeorges T, Theret M, Gondin J, et al. Annexin A1 drives macrophage skewing to accelerate muscle regeneration through AMPK activation. J Clin Invest. 2020;130(3)

[62] Ratnayake D, Nguyen PD, Rossello FJ, Wimmer VC, Tan JL, Galvis LA, et al. Macrophages provide a transient muscle stem cell niche via NAMPT secretion. Nature. 2021;591(7849).

[63] Perdiguero E, Sousa-Victor P, Ruiz-Bonilla V, Jardí M, Caelles C, Serrano AL, et al. p38/MKP-1-regulated AKT coordinates macrophage transitions and resolution of inflammation during tissue repair. J Cell Biol. 2011; 195(2).

[64] Ruffell D, Mourkioti F, Gambardella A, Kirstetter P, Lopez RG, Rosenthal N, et al. A CREB-C/EBPbeta cascade induces M2 macrophage-specific gene expression and promotes muscle injury repair. Proc Natl Acad Sci U S A. 2009;106(41):17475-80.

[65] Saclier M, Lapi M, Bonfanti C, Rossi G, Antonini S, Messina G. The Transcription Factor Nfix Requires RhoAROCK1 Dependent Phagocytosis to Mediate Macrophage Skewing during Skeletal Muscle Regeneration. Cells. 2020;9(3).

[66] Rhys HI, Dell'Accio F, Pitzalis C, Moore A, Norling LV, Perretti M. Neutrophil Microvesicles from Healthy Control and Rheumatoid Arthritis Patients Prevent the Inflammatory Activation of Macrophages. E Bio Medicine. 2018;29.

[67] Moraes LA, Ampomah PB, Lim LHK. Annexin A1 in inflammation and breast cancer: a new axis in the tumor microenvironment. Vol. 12, Cell Adhesion and Migration. 2018.

[68] Schaum N, Karkanias J, Neff NF, May AP, Quake SR, Wyss-Coray T, et al. Single-cell transcriptomics of 20 mouse organs creates a Tabula Muris. Nature. 2018;562 (7727).

[69] Powell-Braxton L, Hollingshead P, Warburton C, Dowd M, Pitts-Meek S, Dalton D, et al. IGF-I is required for normal embryonic growth in mice. Genes Dev. 1993;7 (12 B).

[70] Farrar RP, Lee S, Fernandez A, Le Roith D. Muscle function in mice with IGF-I receptor dysfunction. In: Physiologist. 2020.

[71] Barton ER, Morris L, Musaro A, Rosenthal N, Lee Sweeney H. Muscle-specific expression of insulin-like growth factor I counters muscle decline in $\mathrm{mdx}$ mice. $\mathrm{J}$ Cell Biol. 2002;157(1):137-47.

[72] Barton-Davis ER, Shoturma DI, Sweeney HL. Contribution of satellite cells to IGF-I induced hypertrophy of skeletal muscle. In: Acta Physiologica Scandinavica. 1999.

[73] Tonkin J, Temmerman L, Sampson RD, Gallego-Colon E, Barberi L, Bilbao D, et al. Monocyte/macrophage-derived IGF-1 orchestrates murine skeletal muscle regeneration and modulates autocrine polarization. Mol Ther. 2015;23(7):1189-200.

[74] Cheng M, Nguyen MH, Fantuzzi G, Koh TJ. Endogenous interferon- $\gamma$ is required for efficient skeletal muscle regeneration. Am J Physiol - Cell Physiol. 2008;294(5).

[75] Panduro M, Benoist C, Mathis D. Treg cells limit IFN- $\gamma$ production to control macrophage accrual and phenotype during skeletal muscle regeneration. Proc Natl Acad Sci U S A. 2018;115(11).

[76] Kalovidouris AE, Plotkin Z, Graesser D. Interferon- $\gamma$ inhibits proliferation, differentiation, and creatine kinase activity of cultured human muscle cells. II. A possible role in myositis. J Rheumatol. 1993;20(10). 
[77] Foster W, Li Y, Usas A, Somogyi G, Huard J. Gamma interferon as an antifibrosis agent in skeletal muscle. $\mathrm{J}$ Orthop Res. 2003;21(5).

[78] Ulloa L, Doody J, Massagué J. Inhibition of transforming growth factor- $\beta / S M A D$ signalling by the interferon$\gamma /$ STAT pathway. Nature. 1999;397(6721).

[79] Otis JS, Niccoli S, Hawdon N, Sarvas JL, Frye MA, Chicco AJ, et al. Pro-inflammatory mediation of myoblast proliferation. PLoS One. 2014;9(3).

[80] Deng B, Wehling-Henricks M, Villalta SA, Wang Y, Tidball JG. IL-10 Triggers Changes in Macrophage Phenotype That Promote Muscle Growth and Regeneration. J Immunol. 2012;189(7).

[81] Villalta SA, Rinaldi C, Deng B, Liu G, Fedor B, Tidball JG. Interleukin-10 reduces the pathology of $\mathrm{mdx}$ muscular dystrophy by deactivating M1 macrophages and modulating macrophage phenotype. Hum Mol Genet. 2011;20(4):790-805.

[82] Takagi R, Fujita N, Arakawa T, Kawada S, Ishii N, Miki A. Influence of icing on muscle regeneration after crush injury to skeletal muscles in rats. J Appl Physiol. 2011;110(2).

[83] Urso ML. Anti-inflammatory interventions and skeletal muscle injury: Benefit or detriment? Vol. 115, Journal of Applied Physiology. 2013.

[84] Akira S, Taga T, Kishimoto T. Interleukin-6 in biology and medicine. Adv Immunol. 1993;54.

[85] Pedersen BK, Steensberg A, Schjerling P. Muscle-derived interleukin-6: Possible biological effects. Vol. 536, Journal of Physiology. 2001.

[86] Heredia JE, Mukundan L, Chen FM, Mueller AA, Deo RC, Locksley RM, et al. Type 2 innate signals stimulate fibro/adipogenic progenitors to facilitate muscle regeneration. Cell. 2013;

[87] Wu D, Molofsky AB, Liang HE, Ricardo-Gonzalez RR, Jouihan HA, Bando JK, et al. Eosinophils sustain adipose alternatively activated macrophages associated with glucose homeostasis. Science (80-). 2011;332(6026).

[88] Rana BMJ, Jou E, Barlow JL, Rodriguez-Rodriguez N, Walker JA, Knox C, et al. A stromal cell niche sustains ILC2-mediated type-2 conditioning in adipose tissue. J Exp Med. 2019;216(9).

[89] Brigger D, Riether C, van Brummelen R, Mosher KI, Shiu A, Ding Z, et al. Eosinophils regulate adipose tissue inflammation and sustain physical and immunological fitness in old age. Nat Metab. 2020;2(8).

[90] Ismaeel A, Kim JS, Kirk JS, Smith RS, Bohannon WT, Koutakis P. Role of transforming growth factor- $\beta$ in skeletal muscle fibrosis: A review. Vol. 20, International Journal of Molecular Sciences. MDPI AG; 2019.

[91] Bernasconi P, Blasi C Di, Mora M, Morandi L, Galbiati S, Confalonieri $\mathrm{P}$, et al. Transforming growth factor-b1 and fibrosis in congenital muscular dystrophies. 1999.

[92] Olson LE, Soriano P. Increased PDGFR $\alpha$ Activation Disrupts Connective Tissue Development and Drives Systemic Fibrosis. Dev Cell. 2009;16(2):303-13.

[93] Massague J, Cheifetz S, Endo T, Nadal-Ginard B. Type $\beta$ transforming growth factor is an inhibitor of myogenic differentiation. Proc Natl Acad Sci U S A. 1986;83(21): 8206-10.

[94] Aloysius A, DasGupta R, Dhawan J. The transcription factor Lef1 switches partners from $\beta$-catenin to Smad 3 during muscle stem cell quiescence. Sci Signal. 2018;11(540).

[95] Girardi F, Taleb A, Ebrahimi M, Datye A, Gamage DG, Peccate $\mathrm{C}$, et al. TGF $\beta$ signaling curbs cell fusion and muscle regeneration. Nat Commun. 2021;12(1).
[96] Robertson IB, Horiguchi M, Zilberberg L, Dabovic B, Hadjiolova K, Rifkin DB. Latent TGF- $\beta$-binding proteins. Vol. 47, Matrix Biology. 2015.

[97] Tang K, Breen EC, Wagner H, Brutsaert TD, Gassmann M, Wagner PD. HIF and VEGF relationships in response to hypoxia and sciatic nerve stimulation in rat gastrocnemius. Respir Physiol Neurobiol. 2004;144(1).

[98] Verma M, Asakura Y, Murakonda BSR, Pengo T, Latroche C, Chazaud B, et al. Muscle Satellite Cell Cross-Talk with a Vascular Niche Maintains Quiescence via VEGF and Notch Signaling. Cell Stem Cell. 2018;23(4):530-43.e9.

[99] Emery AEH. Clinical review Fortnightly review The muscular dystrophies [Internet]. 1998. Available from: www.bmj.com.

[100] Rando TA. The dystrophin-glycoprotein complex, cellular signaling, and the regulation of cell survival in the muscular dystrophies. Vol. 24, Muscle and Nerve. 2001;1575-94.

[101] Barton ER, Barton ER. Impact of sarcoglycan complex on mechanical signal transduction in murine skeletal muscle. Am J Physiol Cell Physiol [Internet]. 2006;290:411-9. Available from: http://www.ajpcell.orgc411

[102] Ervasti JM, Campbell KP. Membrane organization of the dystrophin-glycoprotein complex. Cell. 1991;66(6).

[103] Mercuri E, Muntoni F. Muscular dystrophies. Vol. 381, The Lancet. Lancet Publishing Group; 2013;845-60.

[104] Moser H. Duchenne muscular dystrophy: Pathogenetic aspects and genetic prevention*. Vol. 66, Hum Genet. 1984.

[105] Bladen CL, Salgado D, Monges S, Foncuberta ME, Kekou $\mathrm{K}$, Kosma K, et al. The TREAT-NMD DMD global database: Analysis of more than 7,000 duchenne muscular dystrophy mutations. Hum Mutat. 2015;36(4).

[106] Birnkrant DJ, Bushby K, Bann CM, Alman BA, Apkon $\mathrm{SD}$, Blackwell A, et al. Diagnosis and management of Duchenne muscular dystrophy, part 2: respiratory, cardiac, bone health, and orthopaedic management. Vol. 17, The Lancet Neurology. 2018.

[107] Birnkrant DJ, Bushby K, Bann CM, Apkon SD, Blackwell A, Brumbaugh D, et al. Diagnosis and management of Duchenne muscular dystrophy, part 1: diagnosis, and neuromuscular, rehabilitation, endocrine, and gastrointestinal and nutritional management. Vol. 17, The Lancet Neurology. 2018

[108] Hoffman EP, Dressman D. Molecular pathophysiology and targeted therapeutics for muscular dystrophy. Vol. 22, Trends in Pharmacological Sciences. 2001.

[109] Sztretye M, Szabó L, Dobrosi N, Fodor J, Szentesi P, Almássy J, et al. From mice to humans: An overview of the potentials and limitations of current transgenic mouse models of major muscular dystrophies and congenital myopathies. Vol. 21, International Journal of Molecular Sciences. 2020

[110] Pastoret C, Sebille A. rn\& mice show progressive weakness and muscle deterioration with age. Vol. 129, Journal of the Neurological Sciences. 1995.

[111] Bulfield G, Siller WG, Wight PAL, Mooret KJ. X chromosome-linked muscular dystrophy $(\mathrm{mdx})$ in the mouse (animal model). Vol. 81, Proc. Nati. Acad. Sci. USA. 1984.

[112] Cullen MJ, Jaros E. Acta Nmopatholog:ca Ultrastructure of the skeletal muscle in the $\mathrm{X}$ chromosome-linked dystrophic (mdx) mouse Comparison with Duchenne muscular dystrophy*. Vol. 77, Acta Neuropathol. 1988.

[113] Tidball JG, Albrecht DE, Lokensgard BE, Spencer MJ. Apoptosis precedes necrosis of dystrophin-deficient muscle. J Cell Sci. 1995;108(6). 
[114] Muller J, Vayssiere N, Royuela M, Leger ME, Muller A, Bacou F, et al. Comparative evolution of muscular dystrophy in diaphragm, gastrocnemius and masseter muscles from old male mdx mice. J Muscle Res Cell Motil. 2001;22(2).

[115] Stedman HH, Sweeney HL, Shrager JB, Maguire HC, Panettieri RA, Petrof B, et al. The mdx mouse diaphragm reproduces the degenerative changes of Duchenne muscular dystrophy. Nature. 1991;352(6335).

[116] Desguerre I, Arnold L, Vignaud A, Cuvellier S, Yacoubyoussef $\mathrm{H}$, Gherardi RK, et al. A new model of experimental fibrosis in hindlimb skeletal muscle of adult mdx mouse mimicking muscular dystrophy. Muscle and Nerve. 2012;45(6):8030-14.

[117] Dadgar S, Wang Z, Johnston H, Kesari A, Nagaraju K, Chen YW, et al. Asynchronous remodeling is a driver of failed regeneration in Duchenne muscular dystrophy. J Cell Biol. 2014;207(1):139-58.

[118] Deconinck AE, Rafael JA. Utrophin-Dystrophin-Deficient Mice as a Model for Duchenne Muscular Dystrophy. Vol. 90, Cell. 1997.

[119] Zhou L, Rafael-Fortney JA, Huang P, Zhao XS, Cheng G, Zhou X, et al. Haploinsufficiency of utrophin gene worsens skeletal muscle inflammation and fibrosis in mdx mice. $\mathrm{J}$ Neurol Sci. 2008;264(1-2):106-11.

[120] Fukada SI, Morikawa D, Yamamoto Y, Yoshida T, Sumie $\mathrm{N}$, Yamaguchi M, et al. Genetic background affects properties of satellite cells and mdx phenotypes. Am J Pathol. 2010;176(5).

[121] van Putten M, Putker K, Overzier M, Adamzek WA, Pasteuning-Vuhman S, Plomp JJ, et al. Natural disease history of the D2-mdx mouse model for Duchenne muscular dystrophy. FASEB J. 2019;33(7).

[122] Coley WD, Bogdanik L, Vila MC, Yu Q, Van Der Meulen $\mathrm{JH}$, Rayavarapu S, et al. Effect of genetic background on the dystrophic phenotype in mdx mice. Hum Mol Genet. 2016;25(1).

[123] Hammers DW, Hart CC, Matheny MK, Wright LA, Armellini M, Barton ER, et al. The D2.mdx mouse as a preclinical model of the skeletal muscle pathology associated with Duchenne muscular dystrophy. Sci Rep. 2020;10(1).

[124] Young CNJ, Gosselin MRF, Rumney R, Oksiejuk A, Chira N, Bozycki L, et al. Total Absence of Dystrophin Expression Exacerbates Ectopic Myofiber Calcification and Fibrosis and Alters Macrophage Infiltration Patterns. Am J Pathol. 2020;190(1).

[125] Kudoh H, Ikeda H, Kakitani M, Ueda A, Hayasaka M, Tomizuka K, et al. A new model mouse for Duchenne muscular dystrophy produced by $2.4 \mathrm{Mb}$ deletion of dystrophin gene using Cre-loxP recombination system. Biochem Biophys Res Commun. 2005;328(2).

[126] Masubuchi N, Shidoh Y, Kondo S, Takatoh J, Hanaoka K. Subcellular localization of dystrophin isoforms in cardiomyocytes and Phenotypic analysis of dystrophindeficient mice Reveal cardiac myopathy is predominantly caused by a deficiency in full-length dystrophin. Exp Anim. 2013;62(3).

[127] Sharp NJH, Kornegay JN, Van Camp SD, Herbstreith $\mathrm{MH}$, Secore SL, Kettle S, et al. An error in dystrophin mRNA processing in golden retriever muscular dystrophy, an animal homologue of Duchenne muscular dystrophy. Genomics. 1992;13(1).

[128] Kornegay JN. The golden retriever model of Duchenne muscular dystrophy. Vol. 7, Skeletal Muscle. BioMed Central Ltd.; 2017.
[129] Mead AF, Petrov M, Malik AS, Mitchell MA, Childers MK, Bogan JR, et al. Diaphragm remodeling and compensatory respiratory mechanics in a canine model of Duchenne muscular dystrophy. J Appl Physiol [Internet]. 2014;116:807-15. Available from: http://www.jappl.org

[130] Nguyen F, Cherel Y, Guigand L, Goubault-Leroux I, Wyers M. Muscle lesions associated with dystrophin deficiency in neonatal golden retriever puppies. J Comp Pathol. 2002;126(2-3):100-8.

[131] White Z, Hakim CH, Theret M, Yang NN, Rossi F, Cox $\mathrm{D}$, et al. High prevalence of plasma lipid abnormalities in human and canine Duchenne and Becker muscular dystrophies depicts a new type of primary genetic dyslipidemia. J Clin Lipidol. 2020;

[132] Duclos F, Straub V, Moore SA, Venzke DP, Hrstka RF, Crosbie RH, et al. Progressive Muscular Dystrophy in-Sarcoglycan-deficient Mice [Internet]. Vol. 142, The Journal of Cell Biology. 1998. Available from: http://www. jcb.org

[133] Verhaart IEC, Putker K, van de Vijver D, TanganyikaDe Winter CL, Pasteuning-Vuhman S, Plomp JJ, et al. Cross-sectional study into age-related pathology of mouse models for limb girdle muscular dystrophy types $2 \mathrm{D}$ and 2F. PLoS One. 2019;14(8).

[134] Pasteuning-Vuhman S, Putker K, Tanganyika-De Winter CL, Boertje-Van Der Meulen JW, Van Vliet L, Overzier $\mathrm{M}$, et al. Natural disease history of mouse models for limb girdle muscular dystrophy types $2 \mathrm{D}$ and $2 \mathrm{~F}$. PLoS One. 2017;12(8).

[135] Grounds MD, Terrill JR, Al-Mshhdani BA, Duong MN, Radley-Crabb HG, Arthur PG. Biomarkers for Duchenne muscular dystrophy: Myonecrosis, inflammation and oxidative stress. Vol. 13, DMM Disease Models and Mechanisms. Company of Biologists Ltd; 2020.

[136] Mavrogeni S, Papavasiliou A, Spargias K, Constandoulakis P, Papadopoulos G, Karanasios E, et al. Myocardial inflammation in Duchenne Muscular Dystrophy as a precipitating factor for heart failure: a prospective study [Internet]. Vol. 10, BMC Neurology. 2010. Available from: http://www.biomedcentral.com/1471-2377/10/33

[137] Lundberg I, Brengman JM, Engel AG. Analysis of cytokine expression in muscle in inflammatory myopathies, Duchenne dystrophy, and non-weak controls. Vol. 63, Journal of Neuroimmunology ELSEVIER Journal of Neuroimmunology. 1995.

[138] Sun D, Martinez CO, Ochoa O, Ruiz-Willhite L, Bonilla $\mathrm{JR}$, Centonze VE, et al. Bone marrow-derived cell regulation of skeletal muscle regeneration. FASEB J. 2009;23(2):382-95.

[139] Zhang L, Ran L, Garcia GE, Wang XH, Han S, Du J, et al. Chemokine CXCL16 regulates neutrophil and macrophage infiltration into injured muscle, promoting muscle regeneration. Am J Pathol. 2009;175(6):2518-27.

[140] Robertson TA, Maley MAL, Grounds MD, Papadimitriou $\mathrm{JM}$. The role of macrophages in skeletal muscle regeneration with particular reference to chemotaxis. Exp Cell Res. 1993;207(2).

[141] Wehling M, Spencer MJ, Tidball JG. A nitric oxide synthase transgene ameliorates muscular dystrophy in $\mathrm{mdx}$ mice. J Cell Biol. 2001;155(1):123-31.

[142] Giordano C, Mojumdar K, Liang F, Lemaire C, Li $\mathrm{T}$, Richardson $\mathrm{J}$, et al. Toll-like receptor 4 ablation in mdx mice reveals innate immunity as a therapeutic target in Duchenne muscular dystrophy. Hum Mol Genet. 2015;24(8):2147-62. 
[143] Mojumdar K, Liang F, Giordano C, Lemaire C, Danialou $\mathrm{G}$, Okazaki $\mathrm{T}$, et al. Inflammatory monocytes promote progression of Duchenne muscular dystrophy and can be therapeutically targeted via CCR 2. EMBO Mol Med. 2014;6(11):1476-92.

[144] Liang F, Giordano C, Shang D, Li Q, Petrof BJ. The dual CCR2/CCR5 chemokine receptor antagonist Cenicriviroc reduces macrophage infiltration and disease severity in Duchenne muscular dystrophy (DMDmdx-4Cv) mice. PLoS One. 2018;13(3).

[145] Zhao W, Wang X, Ransohoff RM, Zhou L. CCR2 deficiency does not provide sustained improvement of muscular dystrophy in $\mathrm{mdx} 5 \mathrm{cv}$ mice. FASEB J. 2017;31(1):35-46.

[146] Suelves M, Vidal B, Serrano AL, Tjwa M, Roma J, López-Alemany R, et al. uPA deficiency exacerbates muscular dystrophy in MDX mice. J Cell Biol. 2007;178(6): 1039-51.

[147] Madaro L, Torcinaro A, de Bardi M, Contino FF, Pelizzola M, Diaferia GR, et al. Macrophages fine tune satellite cell fate in dystrophic skeletal muscle of mdx mice. PLoS Genet. 2019;15(10).

[148] Villalta SA, Deng B, Rinaldi C, Wehling-Henricks M, Tidball JG. IFN- $\gamma$ Promotes Muscle Damage in the mdx Mouse Model of Duchenne Muscular Dystrophy by Suppressing M2 Macrophage Activation and Inhibiting Muscle Cell Proliferation. J Immunol. 2011;187(10):5419-28.

[149] Villalta SA, Nguyen HX, Deng B, Gotoh T, Tidbal JG. Shifts in macrophage phenotypes and macrophage competition for arginine metabolism affect the severity of muscle pathology in muscular dystrophy. Hum Mol Genet. 2009;18(3):482-96.

[150] Hayden MS, Ghosh S. Signaling to NF- $\kappa$ B. Vol. 18, Genes and Development. 2004. 2195-224.

[151] Acharyya S, Villalta SA, Bakkar N, Bupha-Intr T, Janssen PML, Carathers $\mathrm{M}$, et al. Interplay of IKK/NF- $\kappa \mathrm{B}$ signaling in macrophages and myofibers promotes muscle degeneration in Duchenne muscular dystrophy. J Clin Invest. 2007;117(4):889-901

[152] Radley HG, Davies MJ, Grounds MD. Reduced muscle necrosis and long-term benefits in dystrophic mdx mice after cV1q (blockade of TNF) treatment. Neuromuscul Disord. 2008;18(3):227-38.

[153] Wada E, Tanihata J, Iwamura A, Takeda S, Hayashi YK, Matsuda R. Treatment with the anti-IL-6 receptor antibody attenuates muscular dystrophy via promoting skeletal muscle regeneration in dystrophin-/utrophindeficient mice. Skelet Muscle. 2017;7(1).

[154] Pelosi L, Berardinelli MG, Forcina L, Spelta E, Rizzuto E, Nicoletti $\mathrm{C}$, et al. Increased levels of interleukin-6 exacerbate the dystrophic phenotype in mdx mice. Hum Mol Genet. 2015;24(21).

[155] Kostek MC, Nagaraju K, Pistilli E, Sali A, Lai SH, Gordon $\mathrm{B}$, et al. IL-6 signaling blockade increases inflammation but does not affect muscle function in the mdx mouse. BMC Musculoskelet Disord. 2012;13.

[156] Hamoudi D, Marcadet L, Boulanger AP, Yagita H, Bouredji Z, Argaw A, et al. An anti-RANKL treatment reduces muscle inflammation and dysfunction and strengthens bone in dystrophic mice. Hum Mol Genet. 2019;28(18).

[157] Rando TA, Disatnik MH, Yu Y, Franco A. Muscle cells from mdx mice have an increased susceptibility to oxidative stress. Neuromuscul Disord. 1998;8(1).
[158] Kim JH, Lawler JM. Amplification of proinflammatory phenotype, damage, and weakness by oxidative stress in the diaphragm muscle of mdx mice. Free Radic Biol Med. 2012;52(9).

[159] Rando TA, Crowley RS, Carlson EJ, Epstein CJ, Mohapatra PK. Overexpression of copper/zinc superoxide dismutase: A novel cause of murine muscular dystrophy. Ann Neurol. 1998;44(3).

[160] Lieber RL, Ward SR. Cellular Mechanisms of Tissue Fibrosis. 4. Structural and functional consequences of skeletal muscle fibrosis. J Physiol Cell Physiol [Internet]. 2013;305:241-52. Available from: www.ajpcell.org.

[161] Baghdadi MB, Castel D, Machado L, Fukada SI, Birk DE, Relaix F, et al. Reciprocal signalling by Notch-Collagen V-CALCR retains muscle stem cells in their niche. Nature. 2018;557(7707):714-8.

[162] Urciuolo A, Quarta M, Morbidoni V, Gattazzo F, Molon S, Grumati P, et al. Collagen VI regulates satellite cell selfrenewal and muscle regeneration. Nat Commun. 2013;4.

[163] Morgan J, Rouche A, Bausero P, Houssaïni A, Gross J, Fiszman MY, et al. MMP-9 overexpression improves myogenic cell migration and engraftment. Muscle and Nerve. 2010;42(4).

[164] Serrano AL, Muñoz-Cánoves P. Fibrosis development in early-onset muscular dystrophies: Mechanisms and translational implications. Vol. 64, Seminars in Cell and Developmental Biology. 2017.

[165] Alameddine HS, Morgan JE. Matrix Metalloproteinases and Tissue Inhibitor of Metalloproteinases in Inflammation and Fibrosis of Skeletal Muscles. Vol. 3, Journal of Neuromuscular Diseases. IOS Press; 2016;455-73.

[166] Laumonier T, Menetrey J. Muscle injuries and strategies for improving their repair. Vol. 3, Journal of Experimental Orthopaedics. Springer Berlin Heidelberg; 2016.

[167] Mackey AL, Brandstetter S, Schjerling P, Bojsen-Moller J, Qvortrup K, Pedersen MM, et al. Sequenced response of extracellular matrix deadhesion and fibrotic regulators after muscle damage is involved in protection against future injury in human skeletal muscle. FASEB J. 2011;25(6):1943-59.

[168] Mahdy MAA. Skeletal muscle fibrosis: an overview. Vol. 375, Cell and Tissue Research. Springer Verlag; 2019; 575-88.

[169] Pakshir P, Hinz B. The big five in fibrosis: Macrophages, myofibroblasts, matrix, mechanics, and miscommunication. Vols. 68-69, Matrix Biology. 2018.

[170] Mann CJ, Perdiguero E, Kharraz Y, Aguilar S, Pessina $\mathrm{P}$, Serrano AL, et al. Aberrant repair and fibrosis development in skeletal muscle. Vol. 1, Skeletal Muscle. 2011.

[171] Gosselin LE, Williams JE, Deering M, Brazeau D, Koury $S$, Martinez DA. Localization and early time course of TGF- $\beta 1$ mRNA expression in dystrophic muscle. Muscle and Nerve. 2004;30(5):645-53.

[172] Smith LR, Barton ER. Regulation of fibrosis in muscular dystrophy. Vols. 68-69, Matrix Biology. Elsevier B.V.; 2018;602-15.

[173] Song E, Ouyang N, Hörbelt M, Antus B, Wang M, Exton MS. Influence of alternatively and classically activated macrophages on fibrogenic activities of human fibroblasts. Cell Immunol. 2000;204(1):19-28.

[174] Pessina P, Kharraz Y, Jardí M, Fukada SI, Serrano AL, Perdiguero E, et al. Fibrogenic Cell Plasticity Blunts Tissue Regeneration and Aggravates Muscular Dystrophy. Stem Cell Reports. 2015;4(6):1046-60. 
[175] Fiore D, Judson RN, Low M, Lee S, Zhang E, Hopkins $\mathrm{C}$, et al. Pharmacological blockage of fibro/adipogenic progenitor expansion and suppression of regenerative fibrogenesis is associated with impaired skeletal muscle regeneration. Stem Cell Res. 2016;17(1):161-9.

[176] Uezumi A, Ito T, Morikawa D, Shimizu N, Yoneda T, Segawa M, et al. Fibrosis and adipogenesis originate from a common mesenchymal progenitor in skeletal muscle. J Cell Sci. 2011;124(21):3654-64.

[177] Muñoz-Cánoves P, Serrano AL. Macrophages decide between regeneration and fibrosis in muscle. Vol. 26, Trends in Endocrinology and Metabolism. 2015.

[178] Theret M, Rossi FM V, Contreras O. Evolving Roles of Muscle-Resident Fibro-Adipogenic Progenitors in Health, Regeneration, Neuromuscular Disorders, and Aging [Internet]. Vol. 12, Frontiers in Physiology. 2021; 481. Available from: https://www.frontiersin.org/article/ 10.3389/fphys.2021.673404.

[179] Contreras O, Rossi FM, Theret M. Origins, Potency and Heterogeneity of Skeletal Muscle Fibro-Adipogenic Progenitors - time for new definitions. Skelet Muscle. 2021; Accepted.

[180] Song Y, Yao S, Liu Y, Long L, Yang H, Li Q, et al. Expression levels of TGF- $\beta 1$ and CTGF are associated with the severity of duchenne muscular dystrophy. Exp Ther Med. 2017;13(4):1209-14.

[181] Ishitobi M, Haginoya K, Zhao Y, Ohnuma A, Minato J, Yanagisawa T, et al. Elevated plasma levels of transforming growth factor $\beta 1$ in patients with muscular dystrophy. Neuroreport. 2000;11(18).

[182] Mendias CL, Gumucio JP, Davis ME, Bromley CW, Davis CS, Brooks S V. Transforming growth factor-beta induces skeletal muscle atrophy and fibrosis through the induction of atrogin-1 and scleraxis. Muscle and Nerve. 2012;45(1):55-9.

[183] Liang WC, Tian X, Yuo CY, Chen WZ, Kan TM, Su $\mathrm{YN}$, et al. Comprehensive target capture/nextgeneration sequencing as a second-tier diagnostic approach for congenital muscular dystrophy in Taiwan. PLoS One. 2017;12(2).

[184] Zhou L, Porter JD, Cheng G, Gong B, Hatala DA, Merriam AP, et al. Temporal and spatial mRNA expression patterns of TGF- $\beta 1,2,3$ and T $\beta$ RI, II, III in skeletal muscles of mdx mice. Neuromuscul Disord. 2006;16(1):32-8.

[185] Onofre-Oliveira PCG, Santos ALF, Martins PM, AyubGuerrieri D, Vainzof M. Differential expression of genes involved in the degeneration and regeneration pathways in mouse models for muscular dystrophies. NeuroMolecular Med. 2012;14(1):74-83.

[186] Andreetta F, Bernasconi P, Baggi F, Ferro P, Oliva $\mathrm{L}$, Arnoldi E, et al. Immunomodulation of TGF-beta1 in $\mathrm{mdx}$ mouse inhibits connective tissue proliferation in diaphragm but increases inflammatory response: Implications for antifibrotic therapy. J Neuroimmunol. 2006;175(1-2):77-86.

[187] Travis MA, Sheppard D. TGF- $\beta$ activation and function in immunity. Vol. 32, Annual Review of Immunology. Annual Reviews Inc.; 2014;51-82.

[188] Quattrocelli M, Capote J, Ohiri JC, Warner JL, Vo AH, Earley JU, et al. Genetic modifiers of muscular dystrophy act on sarcolemmal resealing and recovery from injury. PLoS Genet. 2017;13(10).

[189] Nitahara-Kasahara Y, Hayashita-Kinoh H, Chiyo T, Nishiyama A, Okada H, Takeda S, et al. Dystrophic mdx mice develop severe cardiac and respiratory dysfunction following genetic ablation of the anti-inflammatory cytokine IL-10. Hum Mol Genet. 2014;23(15):39904000 .

[190] Vidal B, Serrano AL, Tjwa M, Suelves M, Ardite E, De Mori R, et al. Fibrinogen drives dystrophic muscle fibrosis via a TGF $\beta /$ alternative macrophage activation pathway. Genes Dev. 2008;22(13):1747-52.

[191] Latroche C, Matot B, Martins-Bach A, Briand D, Chazaud B, Wary C, et al. Structural and Functional Alterations of Skeletal Muscle Microvasculature in DystrophinDeficient mdx Mice. Am J Pathol. 2015;185(9):2482-94.

[192] Latroche C, Weiss-Gayet M, Muller L, Gitiaux C, Leblanc P, Liot S, et al. Coupling between Myogenesis and Angiogenesis during Skeletal Muscle Regeneration Is Stimulated by Restorative Macrophages. Stem Cell Reports. 2017;9(6):2018-33.

[193] Li H, Mittal A, Makonchuk DY, Bhatnagar S, Kumar A. Matrix metalloproteinase-9 inhibition ameliorates pathogenesis and improves skeletal muscle regeneration in muscular dystrophy. Hum Mol Genet. 2009;18(14): 2584-98.

[194] Hindi SM, Shin J, Ogura Y, Li H, Kumar A. Matrix Metalloproteinase-9 Inhibition Improves Proliferation and Engraftment of Myogenic Cells in Dystrophic Muscle of mdx Mice. PLoS One. 2013;8(8).

[195] Bobadilla M, Sáinz N, Rodriguez J, Abizanda G, Orbe J, De Martino A, et al. MMP-10 is required for efficient muscle regeneration in mouse models of injury and muscular dystrophy. Stem Cells. 2014;32(2):447-61.

[196] Rasmussen HS, Mccann PP. Matrix Metalloproteinase Inhibition as a Novel Anticancer Strategy: A Review with Special Focus on Batimastat and Marimastat. Vol. 75, Pharmacol. Ther. 1997.

[197] Brown PD. Matrix metalloproteinase inhibitors: A novel class of anticancer agents. Adv Enzyme Regul. 1995; 35(C).

[198] Kumar A, Bhatnagar S, Kumar A. Matrix metalloproteinase inhibitor batimastat alleviates pathology and improves skeletal muscle function in dystrophin-deficient mdx mice. Am J Pathol. 2010;177(1):248-60.

[199] Adams GR, Mccue SA. Localized infusion of IGF-I results in skeletal muscle hypertrophy in rats [Internet]. 1998. Available from: http://www.jap.org

[200] Coleman ME, Demayo F, Kuo Chang Yin, Heung Man Lee, Geske R, Montgomery C, et al. Myogenic vector expression of insulin-like growth factor I stimulates muscle cell differentiation and myofiber hypertrophy in transgenic mice. J Biol Chem. 1995;270(20).

[201] Engert JC, Berglund EB, Rosenthal N. Proliferation precedes differentiation in IGF-I-stimulated myogenesis [Internet]. Vol. 135, Journal of Cell Biology. 1996. Available from: http://rupress.org/jcb/article-pdf/135/2/431/ 1256464/431.pdf

[202] Gregorevic P, Plant DR, Lynch GS. Administration of insulin-like growth factor-I improves fatigue resistance of skeletal muscles from dystrophic mdx mice. Muscle and Nerve. 2004;30(3):295-304.

[203] Pelosi L, Giacinti C, Nardis C, Borsellino G, Rizzuto E, Nicoletti C, et al. Local expression of IGF-1 accelerates muscle regeneration by rapidly modulating inflammatory cytokines and chemokines. FASEB J. 2007;21(7): 1393-402.

[204] Robertson M, Chambers I, Rathjen P, Nichols J, Smith A. Expression of Alternative Forms of Differentiation Inhibiting Activity (DIA/LIF) During Murine Embryogenesis 
and in Neonatal and Adult Tissues. DEVELOPMENTAL GENETICS. 1993.

[205] Hawke TJ, Garry DJ. Myogenic satellite cells: physiology to molecular biology Downloaded from. J Appl Physiol J Appl Physiol Inser U567-Bibliotheque [Internet]. 2001; 534-51. Available from: http://jap.physiology.org/content/ 91/2/534.full\#ref-list-1http://www.theaps.org/.http://jap.physiology.org/

[206] Kurek JB, Bower JJ, Romanella M, Koentgen F, Murphy M, Austin L. The role of leukemia inhibitory farctor in skeletal muscle regeneration. 1997.

[207] Austin L, Bower JJ, Bennett TM, Lynch GS, Kapsa R, White JD, et al. Leukemia inhibitory factor ameliorates muscle fiber degeneration in the mdx MOUSE. Vol. 23, Muscle Nerve. 2000.

[208] Welc SS, Flores I, Wehling-Henricks M, Ramos J, Wang $\mathrm{Y}$, Bertoni $\mathrm{C}$, et al. Targeting a therapeutic LIF transgene to muscle via the immune system ameliorates muscular dystrophy. Nat Commun. 2019;10(1).

[209] Kuro-O* M, Matsumura Y, Aizawa H, Kawaguchi H, Suga $\mathrm{T}$, Utsugi $\mathrm{T}$, et al. Mutation of the mouse klotho gene leads to a syndrome resembling ageing. Vol. 390, Nature. 1997.

[210] Li S-A, Watanabe M, Yamada H, Nagai A, Kinuta M, Takei K. Immunohistochemical Localization of Klotho Protein in Brain, Kidney, and Reproductive Organs of Mice. Vol. 29, CELL STRUCTURE AND FUNCTION. 2004.

[211] Cheikhi A, Barchowsky A, Sahu A, Shinde SN, Pius A, Clemens ZJ, et al. Klotho: An Elephant in Aging Research. Vol. 74, Journals of Gerontology - Series A Biological Sciences and Medical Sciences. 2019.

[212] Wehling-Henricks M, Li Z, Lindsey C, Wang Y, Welc SS, Ramos JN, et al. Klotho gene silencing promotes pathology in the mdx mouse model of Duchenne muscular dystrophy. Hum Mol Genet. 2016;25(12):2465-82.

[213] Thurston RD, Larmonier CB, Majewski PM, Ramalingam R, Midura-Kiela M, Laubitz D, et al. Tumor Necrosis Factor and Interferon- $\gamma$ Down-regulate Klotho in Mice With Colitis. Gastroenterology. 2010;138(4).

[214] Hui H, Zhai Y, Ao L, Cleveland JC, Liu H, Fullerton DA, et al. Klotho suppresses the inflammatory responses and ameliorates cardiac dysfunction in aging endotoxemic mice [Internet]. 2017. Available from: www.impact journals.com/oncotarget.

[215] Zhao Y, Banerjee S, Dey N, LeJeune WS, Sarkar PS, Brobey R, et al. Klotho depletion contributes to increased inflammation in kidney of the $\mathrm{db} / \mathrm{db}$ mouse model of diabetes via RelA (serine)536 phosphorylation. Diabetes. 2011;60(7).

[216] Wehling-Henricks M, Welc SS, Samengo G, Rinaldi C, Lindsey C, Wang Y, et al. Macrophages escape Klotho gene silencing in the mdx mouse model of Duchenne muscular dystrophy and promote muscle growth and increase satellite cell numbers through a Klotho-mediated pathway. Hum Mol Genet. 2018;27(1):14-29.

[217] Icer MA, Gezmen-Karadag M. The multiple functions and mechanisms of osteopontin. Vol. 59, Clinical Biochemistry. 2018.
[218] Das R, Philip S, Mahabeleshwar GH, Bulbule A, Kundu GC. Osteopontin: It's role in regulation of cell motility and nuclear factor $\kappa \mathrm{B}$-mediated urokinase type plasminogen activator expression. Vol. 57, IUBMB Life. 2005.

[219] Capote J, Kramerova I, Martinez L, Vetrone S, Barton ER, Sweeney HL, et al. Osteopontin ablation ameliorates muscular dystrophy by shifting macrophages to a proregenerative phenotype. J Cell Biol. 2016;213(2):275-88.

[220] Griggs RC, Moxley III RT, Fenichel GM, Brooke MH, Pestronk A, Philip Miller J. Prednisone in Duchenne Dystrophy A Randomized, Controlled Trial Defining the Time Course and Dose Response Mendell, MD [Internet]. Available from: http://archneur.jamanetwork.com/.

[221] Sali A, Guerron AD, Gordish-Dressman H, Spurney CF, Iantorno M, Hoffman EP, et al. Glucocorticoid-treated mice are an inappropriate positive control for long-term preclinical studies in the mdx mouse. PLoS One. 2012; 7(4).

[222] Joseph S, Wang C, Bushby K, Guglieri M, Horrocks I, Straub V, et al. Fractures and linear growth in a nationwide cohort of boys with duchenne muscular dystrophy with and without glucocorticoid treatment: Results from the uk northstar database. JAMA Neurol. 2019;76(6):701-9.

[223] Guiraud S, Davies KE. Pharmacological advances for treatment in Duchenne muscular dystrophy. Vol. 34, Current Opinion in Pharmacology. Elsevier Ltd; 2017;36-48.

[224] Bylo M, Farewell R, Coppenrath VA, Yogaratnam D. A Review of Deflazacort for Patients With Duchenne Muscular Dystrophy. Vol. 54, Annals of Pharmacotherapy. 2020.

[225] Hoffman EP, Nader GA. Balancing muscle hypertrophy and atrophy. Vol. 10, Nature Medicine. 2004.

[226] Biggar WD, Politano L, Harris VA, Passamano L, Vajsar J, Alman B, et al. Deflazacort in Duchenne muscular dystrophy: A comparison of two different protocols. Neuromuscul Disord. 2004;14(8-9):476-82.

[227] Hoffman EP, Reeves E, Damsker J, Nagaraju K, McCall JM, Connor EM, et al. Novel Approaches to Corticosteroid Treatment in Duchenne Muscular Dystrophy. Vol. 23, Physical Medicine and Rehabilitation Clinics of North America. 2012;821-8.

[228] Rybalko V, Hsieh PL, Merscham-Banda M, Suggs LJ, Farrar RP. The development of macrophage-mediated cell therapy to improve skeletal muscle function after injury. PLoS One. 2015;10(12).

[229] Bencze M, Negroni E, Vallese D, Yacoubyoussef H, Chaouch S, Wolff A, et al. Proinflammatory macrophages enhance the regenerative capacity of human myoblasts by modifying their kinetics of proliferation and differentiation. Mol Ther. 2012;20(11):2168-79.

[230] Novak JS, Hogarth MW, Boehler JF, Nearing M, Vila MC, Heredia R, et al. Myoblasts and macrophages are required for therapeutic morpholino antisense oligonucleotide delivery to dystrophic muscle. Nat Commun. 2017;8(1).

[231] Mantovani A, Sica A, Sozzani S, Allavena P, Vecchi A, Locati M. The chemokine system in diverse forms of macrophage activation and polarization. Vol. 25, Trends in Immunology. 2004. 